\title{
Therapeutic Vaccination in Chronic Hepatitis B: Preclinical Studies in the Woodchuck
}

\author{
Anna D. Kosinska, Ejuan Zhang, Mengji Lu, and Michael Roggendorf \\ Institute for Virology, University Hospital of Essen, University of Duisburg-Essen, Virchowstraße 179, 45122, Essen, Germany \\ Correspondence should be addressed to Michael Roggendorf, michael.roggendorf@uni-due.de
}

Received 7 June 2010; Accepted 29 July 2010

Academic Editor: Yoichi Hiasa

Copyright ( $) 2010$ Anna D. Kosinska et al. This is an open access article distributed under the Creative Commons Attribution License, which permits unrestricted use, distribution, and reproduction in any medium, provided the original work is properly cited.

\begin{abstract}
Recommended treatment of chronic hepatitis B with interferon- $\alpha$ and/or nucleos(t)ide analogues does not lead to a satisfactory result. Induction of HBV-specific $\mathrm{T}$ cells by therapeutic vaccination or immunotherapies may be an innovative strategy to overcome virus persistence. Vaccination with commercially available HBV vaccines in patients did not result in effective control of HBV infection, suggesting that new formulations of therapeutic vaccines are needed. The woodchuck (Marmota monax) is a useful preclinical model for developing the new therapeutic approaches in chronic hepadnaviral infections. Several innovative approaches combining antiviral treatments with nucleos $(\mathrm{t})$ ide analogues, DNA vaccines, and protein vaccines were tested in the woodchuck model. In this paper we summarize the available data concerning therapeutic immunization and gene therapy using recombinant viral vectors approaches in woodchucks, which show encouraging results. In addition, we present potential innovations in immunomodulatory strategies to be evaluated in this animal model.
\end{abstract}

\section{HBV Infection and Current Treatment Strategies}

World Health Organization estimates that about 2 billion people worldwide have been infected with hepatitis B virus (HBV). Since the introduction of preventive vaccination programs against hepatitis B in over 170 countries, the number of new infections is continuously decreasing. Despite the success of prophylactic vaccines, chronic HBV infection is still a global health problem. Over 360 million people are persistently infected with $\mathrm{HBV}$, of whom 1 million die each year from $\mathrm{HBV}$-associated liver cirrhosis or hepatocellular carcinoma (HCC). The outcome of HBV infection varies greatly from person to person. In most of the cases the infection is cleared spontaneously, however, $5 \%-10 \%$ of adults develop chronic infection. By contrast, 40\%-90\% of children which are born to HBV-infected mothers will progress to develop a persistent liver disease [1].

In the recent, years a marked progress has been made in the treatment of chronic hepatitis B. Currently, the two types of antiviral therapies are approved: treatment with pegylated interferon alpha $2 \mathrm{a}(\mathrm{PEG}-\mathrm{IFN} \alpha)$ or nucleos(t)ide analogues, such as adefovir, entecavir (ETV), lamivudine, telbivudine, and tenofovir [2-5]. However, the efficacy of those therapies in preventing liver cirrhosis and HCC is still limited. Treatment with PEG-IFN $\alpha$ leads to a sustained antiviral response in only one third of patients, regardless of combining the therapy with polymerase inhibitors. On the other hand, the treatment with nucleos $(t)$ ide analogues significantly suppresses HBV replication that leads to a decrease of necroinflammation in the liver. However, those antivirals cannot completely eradicate the virus. After withdrawal of the drug, the rebound of viremia is observed in the majority of patients. Furthermore, the long-term treatment is subsequently associated with the appearance of drugresistant HBV strains that is often the cause of the therapy failure $[6,7]$. Therefore, the new approaches in treating chronic hepatitis B are urgently needed.

\section{Immunological Control of HBV Infection}

It is well documented that an appropriate adaptive immune response is required to efficiently control the HBV infection. $\mathrm{T}$ cell-mediated immune response directed against 
hepatitis $\mathrm{B}$ virus antigens is crucial for resolution of the infection [8-12]. HBV-specific $\mathrm{CD}^{+} \mathrm{T}$ cells are able to clear HBV-infected hepatocytes by secretion of Th1 antiviral cytokines, such as interferons (IFNs) and tumor necrosis factor alpha (TNF $\alpha)$, and direct cytotoxic mechanisms (perforin/granzyme, ligand-ligand induced cell death, e.g., Fas-Fas-L) [12-16]. An early, vigorous, polyclonal, and multispecific cellular immune response against the viral proteins is associated with the clearance of hepatitis $B$ in acutely-infected patients. In contrast, chronic HBV carriers demonstrate weak, transient, or often undetectable $\mathrm{CD} 8^{+}$ T cell response that correlates with HBV persistence [1721]. Humoral immune response, especially neutralizing antienvelope antibodies, play a key role in preventing HBV spread to noninfected hepatocytes $[20,22]$.

Recent studies indicate that several mechanisms may be involved in the loss of the function of HBV-specific $\mathrm{T}$ cells during chronic hepatitis $\mathrm{B}$. It was shown that high-level viremia negatively influences the virus-specific immune responses. High viral replication in the liver with viral load higher than $10^{7}$ copies $/ \mathrm{mL}$ is correlating with hyporesponsiveness of virus-specific $\mathrm{CD}^{+} \mathrm{T}$ cells in patients with chronic hepatitis B [23]. Moreover, the prolonged exposure to viral antigens occurring during the chronic viral infections can trigger the $\mathrm{T}$ cells to become tolerant and prone to apoptosis. The interaction between programmed death 1 (PD-1) receptor and its ligand PD-L1 (also known as B7-H1) plays an important role to prevent an overreaction of the immune system [24]. Recent studies revealed that inhibitory molecules such as PD- 1 and CTLA- 4 are markedly upregulated on virus-specific $\mathrm{T}$ cells, resulting in exhaustion (e.g., lack of IFN $\gamma$ production and proliferation) [25]. Simultaneously, this mechanism can contribute to the development of the chronic infection by impairment of the effective antiviral response. This hypothesis was previously proven for hepatitis $\mathrm{C}$ virus (HCV) $[26,27]$ and human immunodeficiency virus (HIV) infection in humans [2830], as well as lymphocytic choriomeningitis virus (LCMV) infection in mice $[31,32]$, and more recently for HBV $[33,34]$. Furthermore, several studies imply that functional defects of antigen presenting cells (APCs), mainly dendritic cells (DCs), may contribute to the impaired $\mathrm{T}$ cell response in chronic hepatitis B patients [35-41]. In vitro studies showed that DCs isolated from HBV chronic carriers produce lower amount of antiviral cytokines, such as type I interferons and TNF $\alpha$, in comparison to healthy controls $[35,36]$. In addition, those DCs are less efficient in $\mathrm{T}$ cell activation and stimulation of $\mathrm{T}$ cell proliferation $[35,39-41]$. The novel report demonstrated that myeloid DCs from chronic HBV patients express increased level of inhibitory PD-L1 molecule and therefore may down regulate functions of HBV-specific T cells [39]. Several investigations underline the significance of $\mathrm{CD}^{+} \mathrm{CD}^{+} 5^{+}$regulatory $\mathrm{T}$ cells in pathogenesis of persistent viral infections [42]. In HCVand HIV-infected patients, it was shown that regulatory $\mathrm{T}$ cells may downregulate HCV- and HIV-specific $\mathrm{CD}^{+}$ and therefore influence the disease progression [43-45]. The role of regulatory $\mathrm{T}$ cells in HBV infection is still not clear. Nevertheless, the increased numbers of $\mathrm{CD} 4^{+} \mathrm{CD} 25^{+}$ regulatory $\mathrm{T}$ cells were detected in the blood and the liver of patients with chronic severe hepatitis B [46]. In addition, the liver itself is an organ with tolerogenic properties that might contribute to the immunological tolerance during chronic HBV infection [47, 48]. Finally, viruses developed the strategies to efficiently evade the host immune response resulting in persistent infections. Viral immune escape due to the mutation of $\mathrm{CD}^{+}, \mathrm{CD}^{+}$, and $\mathrm{B}$ cell epitopes in a given HLA background have been observed in patients infected with HIV, HCV, and HBV [49-54].

Several studies demonstrate that the treatment with lamivudine alone, or in combination with interleukin-12 (IL-12), result in the restoration of the HBV-specific CD4 ${ }^{+}$ and $\mathrm{CD}^{+}$immune response in chronic HBV-infected individuals. However, the therapeutic effect was not sustained in those patients [55-57].

\section{Clinical Trials of Therapeutic Immunization}

Over 20 years, continuous efforts have been undertaken to develop a therapeutic vaccine for chronic hepatitis B to enhance the virus-specific immune responses and overcome persistent HBV infection [58-71].

Numerous clinical trials of therapeutic immunization exploited the conventional prophylactic hepatitis B surface antigen- (HBsAg-) based protein vaccines. These studies demonstrated reductions in viremia, $\mathrm{HBeAg} /$ anti-HBe seroconversion, and HBV-specific $\mathrm{T}$ cell responses in some patients. However, the anti-viral effect was only transient and did not lead to an effective control of the HBV [58-65]. Combination of the HBsAg protein vaccines with antiviral treatment with lamivudine did not lead to a satisfactory improvement of the therapies [66-68].

The strategies designed to specifically stimulate HBVspecific $\mathrm{T}$ cell responses were also not successful [69-71]. The lipopeptide-based vaccine containing a single cytotoxic $\mathrm{T}$ lymphocyte (CTL) epitope derived from HBV nucleocapsid was able to induce a vigorous primary $\mathrm{HBV}$-specific $\mathrm{T}$ cell response in naïve subjects [76]. However, in HBV chronic carriers, the vaccine initiated only poor CTL activity and had no effect on viremia or $\mathrm{HBeAg} / \mathrm{anti}-\mathrm{HBe}$ seroconversion [69]. The DNA vaccine expressing small and middle envelope proteins proved to elicit the HBV-specific cellular immune response in chronic HBV carriers, however, this effect was only transient [70].

Yang et al. presented the novel DNA vaccine for treatment of chronic hepatitis and combined the immunizations with lamivudine treatment [71]. The multigene vaccine contains five different plasmids encoding most of HBV antigens and human IL-12 gene as a genetic adjuvant. The combination therapy led to sustained antiviral response in 6 out of 12 HBV chronically infected patients. The responders were able to clear HBeAg and had undetectable viral load at the end of a 52-week follow-up. Those effects were correlating with a detectable T cell response to at least one of the HBV antigens. [71]. Nevertheless, further studies are needed to evaluate this strategy on a larger cohort of HBV chronic carriers.

The therapeutic vaccine-based HBsAg complexed with human anti-HBs was proposed by the group of Wen et al. 
[77]. Immunogenic complexes (ICs) stimulate robust T cell responses by increasing uptake of HBsAg through Fc receptors on APCs and, therefore, modulate $\mathrm{HBsAg}$ processing and presentation. It was demonstrated that this vaccine administered to $\mathrm{HBeAg}$-positive patients led to decrease of HBV DNA in serum, HBeAg seroconversion, and development of anti-HBs in part of the subjects [78]. Currently, the IC-based vaccine is the only one that entered phase III of clinical trials in chronic hepatitis B patients [79]. Even though the IC-based vaccine led to antiviral effect, clearance of HBV was not observed in treated patients. It seems that the vaccine alone is not sufficient to achieve the full control over HBV. Therefore, some steps have been undertaken to combine the IC-based vaccine with nucleos(t)ide analogues treatment, (Wen et al., personal communication). The ongoing clinical trial will show whether IC are effective as a therapeutic vaccine in chronic hepatitis $\mathrm{B}$.

\section{Transgenic Mouse Model for Studies on Therapeutic Immunization}

Over the years, various animal models, including chimpanzees, woodchucks, ducks, and HBV transgenic mice, were established for development and evaluation of novel therapeutic strategies. Considering the cost, ethical reasons, and available amount, HBV transgenic mice are the most widely used models. Studies using HBV transgenic mouse models demonstrated that DNA immunization with the expression plasmids encoding different HBV proteins could induce HBV-specific antibodies and stimulate CTL responses. However, the functionality of HBV-specific CTLs induced in transgenic mice may be not fully developed [80-82]. Improvement of DNA vaccination regimen [83] and blockade of PD-1/PD-L1 interaction [34, 84] could enhance functional $\mathrm{T}$ cell responses and lead to inhibition of viral replication in vivo without causing hepatitis. Apart from the DNA immunizations, the other therapeutic approaches including administration of Toll-like receptor (TLR) ligands, HBV-specific siRNA, and direct activation of APCs were evaluated in HBV transgenic mice [8587]. Those strategies were able to effectively reduce the HBV replication, and are currently under investigation as combined therapies. Nevertheless, this model has a significant limitation. As the HBV genome is inserted into the mouse chromosome, full HBV life cycle does not take place in the transgenic mice and no liver inflammation can be observed [88]. Thus, the animal models with naturally occurring hepadnaviral infection are required for the longterm evaluation of the therapeutic effect. In comparison to chimpanzees, woodchucks are easily available and affordable.

In this paper we would like to introduce woodchucks as a useful preclinical model for designing of the new therapeutic vaccines in chronic hepadnaviral infections. We will summarize the available data concerning therapeutic immunization approaches in woodchucks and present potential innovations in immunomodulatory strategies that yet to be evaluated on this animal model.

\section{The Woodchuck as a Preclinical Model for Pathogenesis and Therapy of Chronic Hepatitis B}

The Eastern woodchuck (Marmota monax) is naturally infected by woodchuck hepatitis virus (WHV). WHV was discovered in 1978 as a virus closely related to HBV [89] and classified as a member of Hepadnaviridae family. WHV and HBV show a marked similarity in the virion structure, genomic organization, and the mechanism of replication, but differ in several aspects, for example, regulation of transcription (Table 1) [90]. WHV causes acute self-limiting and chronic infection similar to HBV infection in the pathogenesis and profiles of the virus-specific immune response [91]. This feature of the woodchuck model makes it so significant for investigation of the new therapeutic approaches in chronic hepatitis B.

Experimental infection of neonates or adult woodchucks with WHV reflects the outcome of HBV infection in humans. In adult woodchucks infection with WHV usually leads to the resolution of infection and only $5 \%-10 \%$ of animals will develop the chronic hepatitis. The exposure of woodchuck, neonates to WHV results in development of chronic WHV infection in $60 \%-75 \%$ of the cases [92]. The continuous replication of WHV in the liver during the chronic infection is nearly always associated with development of HCC in the woodchucks $[93,94]$. After diagnosis of HCC the survival prognosis of the animals is estimated on about 6 months, like in humans. The common features of HBV- and WHVinduced carcinogenesis give the opportunity to examine the new anti-HCC therapies in the woodchucks [95].

For many years, the studies on immunopathogenesis of WHV infection in woodchucks were restricted to determination of humoral immune responses [96]. The lack of appropriate methods to evaluate antigen-specific $\mathrm{T}$ cell responses was the serious limitation of this model.

Proliferation assay for peripheral blood mononuclear cells (PBMCs) based on incorporation of $\left[{ }^{3} \mathrm{H}\right]$-thymidine by cellular DNA, routinely used for human and mouse system, has been ineffective in the woodchuck PBMCs $[97,98]$. The failure of this approach is consistent with the fact that woodchuck lymphocytes do not express the thymidine kinase gene (Menne et al., unpublished results). This obstacle had been overcome by usage of the alternative radioactively labeled nucleotide $2\left[{ }^{3} \mathrm{H}\right]$-adenine [72]. Development of $2\left[{ }^{3} \mathrm{H}\right]$-adenine-based proliferation assay enabled to detect the T-helper lymphocyte responses after stimulation of woodchuck PBMCs with WHV core, surface and X antigens (WHcAg, WHsAg, and WHxAg, resp.) [72, 99]. In addition, using the $2\left[{ }^{3} \mathrm{H}\right]$-adenine-based proliferation assay in PBMCs from acutely infected animals, several T-helper epitopes within WHcAg [72] and WHsAg were identified [Menne et al., unpublished results].

Recently established, a novel CD107a degranulation assay for woodchuck PBMCs and splenocytes made a significant breakthrough in studying pathogenesis of hapadnaviral infections in the woodchuck model [73]. Several studies demonstrated that detection of CD107a, as a degranulation marker, is a suitable method for determination of antigen 
TABLE 1: Virological and clinical comparison between HBV and WHV.

\begin{tabular}{|c|c|c|}
\hline & $\mathrm{HBV}$ & WHV \\
\hline \multicolumn{3}{|l|}{ Virology } \\
\hline \multirow{2}{*}{ Classification } & Family: Hepadnaviridae & Family: Hepadnaviridae \\
\hline & Genus: Orthohepadnavirus & Genus: Orthohepadnavirus [91] \\
\hline Host & Human & Woodchuck (Marmota monax) \\
\hline Structure & $\begin{array}{l}40-42 \mathrm{~nm} \text { spherical; enveloped nucleocapsid; } \\
\text { partially double-stranded DNA genome [22] }\end{array}$ & $\begin{array}{l}42-45 \mathrm{~nm} \text { spherical; enveloped } \\
\text { nucleocapsid; partially double-stranded } \\
\text { DNA genome }[91,104]\end{array}$ \\
\hline Proteins & $\begin{array}{l}\text { Surface glycoproteins (large-L, medium-M, } \\
\text { small-S), core protein, "x" protein, "e" antigen, } \\
\text { DNA polymerase with reverse-transcriptase } \\
\text { activity }[22,105]\end{array}$ & The corresponding proteins [91] \\
\hline Replication strategy & $\begin{array}{l}\text { Replication of HBV DNA occurs by reverse } \\
\text { transcription of an RNA intermediate within } \\
\text { cytoplasmic nucleocapsids [22] }\end{array}$ & The same mechanism [97] \\
\hline Genetic diversity & 8 major genotypes [105] & $\begin{array}{l}1 \text { major genotype (minor sequence } \\
\text { differences) [91] }\end{array}$ \\
\hline Integration into host chromosome & Yes $[22]$ & $\begin{array}{l}\text { Yes, often close to N-myc oncogene } \\
\text { region [106] }\end{array}$ \\
\hline \multicolumn{3}{|l|}{ Clinical course of infection } \\
\hline Epidemic & 350 million people infected worldwide & $\begin{array}{l}\text { Endemic in some woodchuck population } \\
\text { in North America }\end{array}$ \\
\hline Vertical transmission & The most common: from mother to newborn & $\begin{array}{l}\text { Neonatal woodchucks infected by WHV } \\
\text { inoculum }\end{array}$ \\
\hline & chronicity rate: $45 \%-90 \%[20,105]$ & chronicity rate: $60 \%-75 \%[92]$ \\
\hline Horizontal transmission & $\begin{array}{l}\text { Transmitted by body fluids, } 90 \% \text { of individuals } \\
\text { recover [105] }\end{array}$ & $\begin{array}{l}\text { Adult woodchucks infected by WHV } \\
\text { inoculum, } 90 \%-95 \% \text { of animals recover } \\
{[92]}\end{array}$ \\
\hline \multirow{3}{*}{ Clinical features of chronic infection } & Variable HBV DNA levels: $10^{4}-10^{12}$ copies $/ \mathrm{mL}$ & WHV DNA levels: $10^{9}-10^{11}$ copies $/ \mathrm{mL}$ \\
\hline & Variable HBsAg levels & WHsAg: mean 100-300 ug/mL \\
\hline & liver transaminases elevation $[20,22,105]$ & liver transaminases elevation $[92,107]$ \\
\hline \multicolumn{3}{|l|}{ Disease progression } \\
\hline Liver cirrhosis & $\begin{array}{l}2 \%-5 \% \text { in HBeAg-positive patients (genotype } \\
\text { dependent) }[20]\end{array}$ & Not common \\
\hline Hepatocellular carcinoma & $\begin{array}{l}\text { 5-year cumulative HCC incidence in patients with } \\
\text { cirrhosis: } 16 \% \text { (data in Asia) [20] }\end{array}$ & $\begin{array}{l}\text { Nearly } 100 \% \text { of chronic infected animals } \\
\text { have HCC after } 3 \text { years }[92,94,95,107]\end{array}$ \\
\hline \multirow{2}{*}{$\begin{array}{l}\text { Efficacy of nucleos(t)ide analogues } \\
\text { treatment }\end{array}$} & \multirow{2}{*}{$\begin{array}{l}\text { Effective: entecavir, tenofovir, telbivudine, } \\
\text { adefovir, lamivudine }[2-5]\end{array}$} & $\begin{array}{l}\text { Effective: clevudine, telbivudine, } \\
\text { entecavir, emtricitabine, tenofovir, }\end{array}$ \\
\hline & & $\begin{array}{l}\text { Less effective: tenofovir, adefovir, } \\
\text { lamivudine }[74,108-118]\end{array}$ \\
\hline Development of resistance mutations & Yes $[6,7,105]$ & $\begin{array}{l}\text { Lamivudine-resistant strains isolated } \\
\text { [119] }\end{array}$ \\
\hline
\end{tabular}

specific cytotoxic $\mathrm{T}$ lymphocytes $[100,101]$. The assay enables detection of WHV-specific CTLs basing on their granule-dependent effector function. Recognition of the infected cells by CTLs results in the exposure of CD107a molecule on the CTL surface. In the woodchuck system, CD107a molecule can be stained by cross-reactive antimouse CD107a antibody, what enables the flow cytometric analysis of the woodchuck CTLs.

Introduction of those immunological tools for studying of the $\mathrm{T}$ cell response in woodchucks revealed a significant similarity between the pathogenesis of WHV infection in woodchucks and HBV in humans. It was demonstrated that acute self-limiting and resolved WHV infections correlate with robust multifunctional T-helper and cytotoxic $\mathrm{T}$ cell responses [72, 73, 99]. Moreover, this efficient cellular immune response to viral antigens results in the liver injury and is necessary for viral clearance. With the novel CD107a degranulation assay, one immunodominant CTL epitope within WHcAg (aa 96-110) [73] and one CTL epitope within the WHsAg (aa 220-234, Frank et al., unpublished results) 


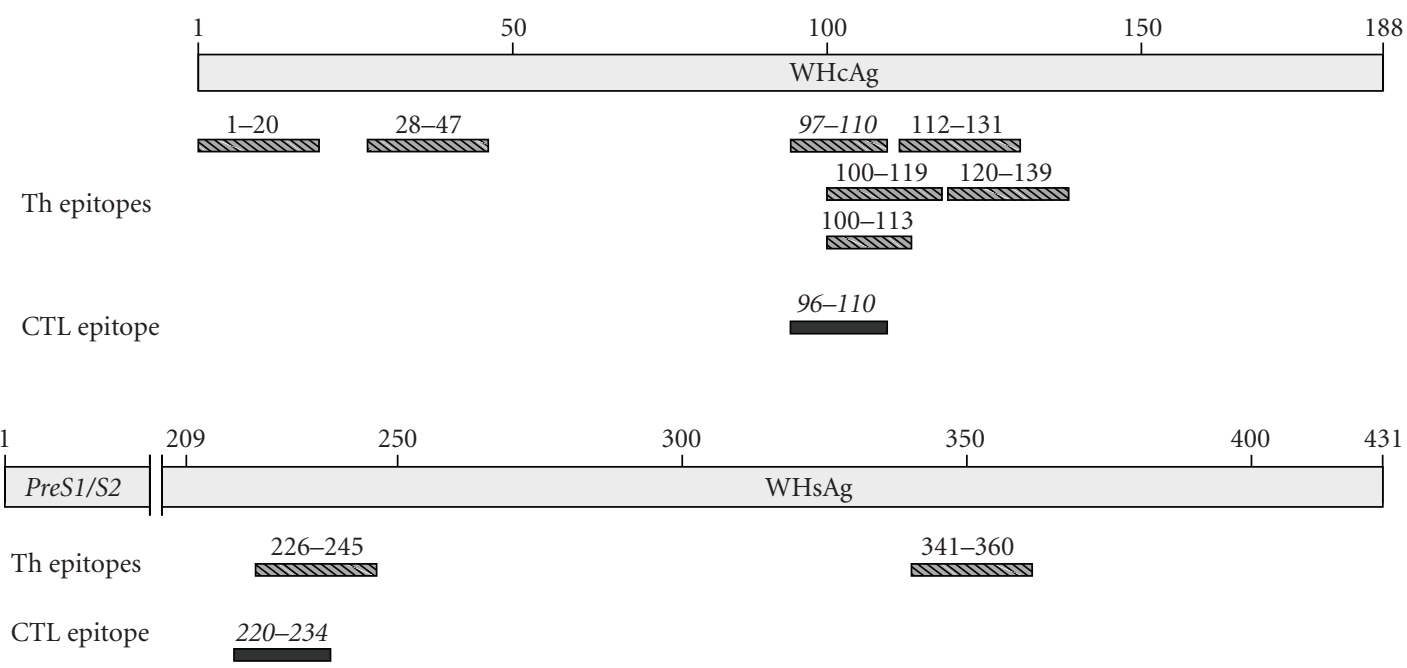

Figure 1: $\mathrm{CD}^{+} / \mathrm{CD}^{+} \mathrm{T}$ cell epitopes in WHcAg and WHsAg in woodchucks. Immunodominant epitopes' sequences are labelled in italics [72-75].

were characterized (Figure 1). In contrast to self-limiting infection, WHV chronic carriers demonstrate weak or no virus-specific $T$ cell responses against the identified epitopes $[72,73,99]$.

The establishment of the assays for monitoring of cellular immune response in woodchucks is of great importance for a reliable evaluation of therapeutic and immunomodulatory strategies for treatment of chronic hepatitis B in the woodchuck model $[96,102,103]$.

\section{Therapeutic Vaccination Approaches in the Woodchuck Model}

Recently described advancements in the characterization and monitoring of the woodchuck immune system during the WHV infection, made this animal model particularly useful for development of the immunomodulatory approaches in chronic hepatitis $\mathrm{B}$. The natural occurrence of chronic WHV infection in woodchucks, that is closely related to HBV infection in humans, allows to evaluate the potentially new therapeutic strategies directly in chronic WHV carriers. Up to date, several studies of diverse therapeutic vaccinations have been carried out in woodchucks (Table 2).

The pioneer investigations based on therapeutic vaccines based on WHV core [96] or surface antigens in combination with a helper peptide FIS [120], or with potent Th1 adjuvants like monophosphoryl lipid A [121] did not lead to satisfactory results. Those experiments proved that vaccinations could induce specific B- and/or T cell responses in chronic WHV carriers. However, this alone was not sufficient to achieve the control of virus replication.

It is assumed that high level viremia, during the chronic hepatitis $B$, can inhibit the therapeutic effect of the vaccination. Treatment of chronic HBV patients with lamivudine could transiently restore $\mathrm{HBV}$-specific $\mathrm{T}$ cell immune response $[55,56]$. Therefore, reduction of viral load by the nucleos(t)ide analogues pretreatment might support the efficacy of immunization to enhance the virus-specific immune responses. This hypothesis was tested in three experimental trials of the combination therapies in chronic WHV carriers.

The first study performed by Hervás-Stubbs et al. was based on lamivudine therapy [108]. Five chronically WHVinfected woodchucks were treated orally with the drug for 23 weeks. At week 10, after decline of WHV DNA by 3-5 logs, three animals were vaccinated with 3 doses of serum-purified WHsAg combined with T-helper FIS peptide derived from sperm whale myoglobin. The vaccination induced T-helper responses against WHV antigens, shifting the cytokine profile from Th2 to Th0/Th1. However, no beneficial effect on WHV viral load and WHsAg levels was observed in comparison to nonimmunized animals. After withdrawal of the lamivudine treatment the values of viremia returned to the pre-treatment levels.

The second trial evaluated the therapy with a very potent antiviral drug: clevudine (previously called L-FMAU) combined with a WHsAg-based immunization [74, 109, 110]. A large cohort of thirty 1-2-year-old chronically WHVinfected woodchucks was enrolled in the study. Half of the animals were orally treated with clevudine $(10 \mathrm{mg} / \mathrm{kg} /$ day $)$ for 32 weeks; the other 15 woodchucks received placebo. After withdrawal of clevudine treatment, 8 animals from each group were vaccinated with the four doses of formalin inactivated alum-adsorbed WHsAg and 7 were injected with the saline as a control. Combination of the drug and vaccine therapy resulted in marked reductions WHV DNA (68 logs) and WHsAg in serum during the 60-week monitoring period, in contrast to the vaccine only and placebo groups, where both markers remained at high levels. Combination therapy did not enhanced anti-WHs responses beyond those measured for vaccine alone. However, treatment with clevudine and vaccine together led to more sustained and robust lymphoproliferative responses to $\mathrm{WHsAg}$ and additionally to WHcAg, WHeAg, and WHxAg. Moreover, combination therapy delayed the onset of the liver disease and prevented 
TABLE 2: Studies on therapeutic vaccinations in the woodchuck model.

\begin{tabular}{|c|c|c|c|c|}
\hline Vaccines & Application & Adjuvants & Outcome & Reference \\
\hline WHcAg & intramuscular & & Viral elimination in 1 of 6 animals & $\begin{array}{l}\text { Roggendorf et al., } \\
1995 \text { [96] }\end{array}$ \\
\hline WHsAg and Th-peptide & intramuscular & Th-peptide & $\begin{array}{l}\text { Transient anti-WHs antibody response } \\
\text { Two woodchucks died }\end{array}$ & $\begin{array}{l}\text { Hervás-Stubbs et al., } \\
1997[120]\end{array}$ \\
\hline WHsAg and Th-peptide & intramuscular & Th-peptide & $\begin{array}{l}\text { No induction of anti-WHs antibodies } \\
\text { Detectable T-cell responses to WHV } \\
\text { proteins }\end{array}$ & $\begin{array}{l}\text { Hervás-Stubbs et al., } \\
2001[108]\end{array}$ \\
\hline $\begin{array}{l}\text { WHsAg in combination } \\
\text { with clevudine (L-FMAU) }\end{array}$ & intramuscular & alum & $\begin{array}{l}\text { Reduction of serum viral loads and } \\
\text { viral replication in liver } \\
\text { Induction of anti-WHs and detection } \\
\text { of T-cell responses to WHV proteins } \\
\text { Delayed occurrence of HCC }\end{array}$ & $\begin{array}{l}\text { Menne et al., 2000, } \\
2002[74,109,110]\end{array}$ \\
\hline WHsAg & intramuscular & $\begin{array}{l}\text { monophosphoryl } \\
\text { lipid A }\end{array}$ & $\begin{array}{l}\text { No reduction of serum viral load, } \\
\text { Development of antibodies to the preS } \\
\text { region of WHsAg }\end{array}$ & Lu et al., 2003 [121] \\
\hline $\begin{array}{l}\text { Plasmid DNA expressing } \\
\text { WHsAg, WHcAg, and } \\
\text { woodchuck IFN- } \gamma \text { in } \\
\text { combination with } \\
\text { lamivudine }\end{array}$ & intramuscular & $\varnothing$ & $\begin{array}{l}\text { Transient reduction of serum viral } \\
\text { loads }\end{array}$ & Lu et al., 2008 [112] \\
\hline $\begin{array}{l}\text { WHsAg/anti-WHs } \\
\text { immunogenic complex and } \\
\text { DNA vaccines in } \\
\text { combination with } \\
\text { lamivudine }\end{array}$ & intramuscular & $\varnothing$ & $\begin{array}{l}\text { Transient reduction of serum viral } \\
\text { loads } \\
\text { Transient appearance of anti-WHs } \\
\text { antibodies and WHcAg-specific T cell } \\
\text { response }\end{array}$ & Lu et al., 2008 [112] \\
\hline $\begin{array}{l}\text { Plasmid DNA encoding } \\
\text { WHsAg and WHcAg in } \\
\text { combination with entecavir }\end{array}$ & intramuscular & $\varnothing$ & $\begin{array}{l}\text { Transient reduction of serum viral } \\
\text { loads }\end{array}$ & $\begin{array}{l}\text { Lu et al., } \\
\text { [unpublished results] }\end{array}$ \\
\hline $\begin{array}{l}\text { Plasmid DNA encoding } \\
\text { WHsAg and WHcAg in } \\
\text { combination with protein } \\
\text { WHsAg/WHcAg vaccine in } \\
\text { combination with entecavir }\end{array}$ & intramuscular & $\varnothing$ & & \\
\hline
\end{tabular}

HCC development in up to $38 \%$ of treated chronic WHV carriers in the long-term follow-up study [111].

Recently, a novel therapeutic approach for treatment of chronic hepatitis B in a woodchuck model was described. The therapy combined the antiviral treatment with immunization with plasmid DNA and antigen-antibody immunogenic complex vaccines together [112]. DNA vaccines are considered to stimulate both humoral and cellular immune response, polarizing $\mathrm{T}$ cells in the direction of $\mathrm{Th} 1$ response [122]. Immunization of the naïve woodchucks with the plasmids encoding WHV core and preS2/S genes (pWHcIm and pWHsIm, resp.) induced the lymphoproliferative responses against the antigens and provided a protection against WHV challenge [123]. In addition, the DNA vaccine expressing HBsAg proved to elicit the vigorous $\mathrm{T}$ cell responses in chronic HBV carriers, however, this effect was only transient [70]. The HBsAg/anti-HBs IC vaccine is currently under the investigation in chronic HBV patients [77-79].

To evaluate the efficacy of previously mentioned immunotherapy in woodchucks, firstly 10 chronic WHV carriers were treated with $15 \mathrm{mg}$ of lamivudine, daily for 21 weeks. At week 10, four animals were pretreated with cardiotoxin and then received three immunizations with DNA vaccine containing three plasmids expressing WHsAg, WHcAg, and woodchuck IFN $\gamma$ (pWHsIm, pWHcIm and pWIFN, resp.). Simultaneously, the other four woodchucks received three doses of the combination of DNA vaccine and WHsAg/anti-WHs immunogenic complex. Two chronic WHV carriers served as lamivudine monotherapy control. Lamivudine treatment resulted in only a slight decrease of WHV DNA levels in the woodchucks serum $(0,7$ and $0,32 \mathrm{log}$, resp.). Surprisingly, the DNA vaccination did not lead to any additional therapeutic effect beyond that observed for lamivudine treatment alone. In contrast, the triple combination of antiviral treatment, plasmid DNA encoding WHcAg, WHsAg, and wIFN $\gamma$ and IC vaccines was able to decrease WHV viral load up to 2,9 log and the serum WHsAg up to $92 \%$. Moreover, three of the four treated animals developed anti-WHs antibodies. Nevertheless, these effects were not sustained and all parameters reached the baseline levels shortly after withdrawal of lamivudine treatment. In addition, the vaccination did not induce WHVspecific $\mathrm{T}$ cell responses in the majority of woodchucks, even in animals that exhibited virological responses. Significant 
lymphoproliferative responses against WHV antigens were detected only in one animal after three immunizations with DNA vaccine [112]. The study demonstrated the benefit of using the combinatory therapy in chronically WHVinfected woodchucks. However, the transient therapeutic effects, suggest that this strategy needs further optimization.

The results from the previous studies clearly confirm the poor efficacy of the lamivudine therapy in woodchucks $[108,112,124]$. A new strategy evaluated the potency of an entecavir treatment and increased number of immunizations [Lu et al., unpublished results]. Chronically WHV-infected woodchucks were pretreated with the entecavir for 21 weeks; 10 weeks in a daily and 11 weeks in a weekly manner. During the weekly administration of the drug, one group of animals received 6 immunizations with two-plasmid DNA vaccine (pWHsIm and pWHcIm), the second group received combination of DNA vaccine together with purified WHV core and surface antigens, and the third group remained untreated. The entecavir therapy resulted in rapid and significant decrease of the viral load and WHsAg levels in serum of the animals. The effect was especially pronounced in animals that additionally received vaccines. In woodchucks treated only with entecavir, the increase of viremia was observed already during the weekly administration or immediately after withdrawal of the drug. By contrast, in both groups of animals, that were immunized with DNA or DNA/proteins vaccines, the delay before the rebound of WHV replication was significantly prolonged. In addition, entecavir treatment was effective to suppress WHV replication and enhanced the induction of WHV-specific T cell responses. An increased CTL activity was detected in individual woodchucks after DNA or DNA/proteins vaccinations. Moreover, two animals completely eliminated the virus from the blood and were WHV DNA negative in the liver [Lu et al., unpublished results].

Altogether, the results obtained in the woodchuck model concerning combination of nucleot(s)ide therapy and immunization proved the synergistic effect of both therapeutical approaches. The therapeutic effects observed during such therapies were significantly increased and prolonged in comparison to the monotherapy alone. In addition, those therapeutic approaches could stimulate the WHV-specific T cell responses, usually impaired in WHV chronic carriers [72, 73]. A combination of antiviral treatment and vaccination is required for the improvement of virus specific $\mathrm{T}$ cell responses. Designing of the future therapeutic approaches should include pretreatment with the potent antiviral drugs, such as entecavir or clevudine, that proved their efficacy in the woodchuck model.

\section{Therapeutic Immunization Using Recombinant Viral Vectors and Prime-Boost Strategy}

Previous results from therapeutic immunization trials on woodchucks, chimpanzees, and humans indicate that the licensed vaccines are not able to boost a functional antiviral $\mathrm{T}$ cell response. There is a need to use more potent strategies.
Vaccines based on recombinant viruses have gained a great interest because of their ability to stimulate robust humoral and cellular immune responses. Viral vectors were investigated as prophylactic and therapeutic vaccines against many human pathogens such as measles virus, herpes simplex virus (HSV), human papillomavirus (HPV), HIV, and rabies [126130]. However, the utility of those recombinant vaccines in the treatment of chronic hepatitis B was not yet evaluated.

Preliminary results obtained from the study in chronically HBV-infected chimpanzees immunized with retroviral vector, based on Moloney murine leukemia virus, encoding $\mathrm{HBcAg}$ suggest that further investigation of viral-vector based vaccines should be taken into consideration [131]. In the experiment, one of the three therapeutically immunized chronic carrier chimpanzees cleared the virus and showed HBeAg seroconversion. Significant ALT elevations observed in this animal implicate restoration of $\mathrm{HBV}$-specific cytotoxic and humoral responses without causing fulminant hepatitis. Moreover, the other two chimpanzees demonstrated high anti-HBe titers after the therapy and one of them HBcAgspecific CTLs [131]. This study demonstrates not only the benefit of using the recombinant viral-vectors for treatment of chronic HBV infection in primate model, but also the possible advantage of using core antigen-based therapeutic vaccines. Even though the retroviral vector vaccination was well tolerated in the chimpanzees, several clinical trials suggest that gene therapy with traditional retroviral vectors can lead to oncogenesis $[132,133]$. Therefore, the usage of another recombinant virus as a carrier of the proteins could be beneficial.

\section{Recombinant Adenoviruses as the Vaccines}

Recombinant adenoviruses have been one of the intensively investigated viral vectors for therapeutic purposes. Development of the novel methods for manipulating of the viral genome resulted in the three generations of the recombinant adenoviruses and with increasing capacity [125] (Figure 2). Several trials imply the usefulness of those vectors in gene therapy of genetic diseases and cancer [134-137]. For many years, the first generation replication-deficient E1 or E1/E3-deleted adenoviral vectors have been explored as the vaccine carriers in prevention of the infectious diseases [138]. Adenoviral vectors have several advantages that can be beneficial for potent therapeutic vaccines.

First of all, adenoviruses are relatively susceptible for genetic modifications and can be easily produced in high titers. After transduction of the cells, adenoviral genome is not integrated into the host DNA and stays in the episomal form. As a result, the risk of the possible activation of the cellular oncogenes is minimal. Adenovirusbased vaccines proved to elicit a vigorous and sustained humoral and $\mathrm{T}$ cell responses to the incorporated antigen that is considered to be crucial in clearance of persistent viral diseases [127, 139-141]. The benefit of adenoviral vectors as a vaccine carrier is not only limited to stable delivery of proteins of interest. Several findings on additional immunostimulatory effects, for example, induction of the innate immune response, that originate from the nature 

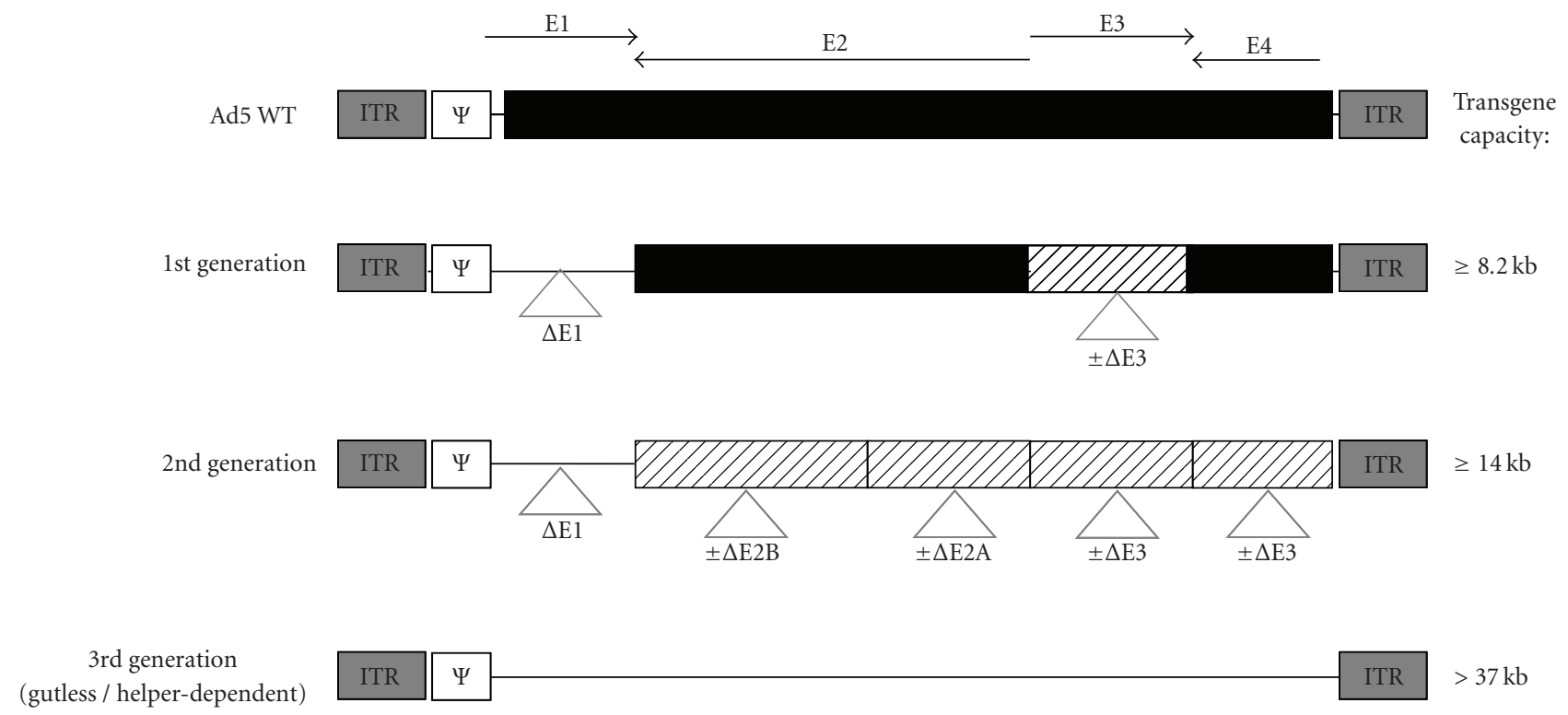

FIgURE 2: Genome structures of the first, second, and third generation of adenoviral vectors. Wild-type adenoviral sequences are labelled in black. The localization of the early genes (E1-E4) is represented by arrows. Deletion sites are shown as a thin line or as striped boxes for alternative deletions. ITR: inverted terminal repeats; $\Psi$ : packaging signal (modified from: X. Danthinne [125]).

of adenoviruses itself, may enhance the vaccine efficacy. Capsid of adenoviruses demonstrates immunostimulatory properties, that is why the coadministration of the adjuvant is usually unnecessary. Those vectors can directly transduce DCs causing their maturation and upregulation of MHC and costimulatory molecules on their surface, thus lead to enhanced antigen presentation. Moreover, it was shown that AdV-transduced DCs are secreting antiviral cytokines, such as IFN $\alpha, \operatorname{TNF} \alpha$, and IL-6 [142]. Interleukin-6 is one of the most important factors that suppress the function of the regulatory T cells $[143,144]$.

Nevertheless, modified adenoviruses apart from the abovementioned advantages have one serious limitation. Thus far, vectors that were comprehensively examined as the vaccines have been based on the human adenovirus serotype 5 (Ad5) [127]. This serotype is the most common in the human population. Anti-Ad5 neutralizing antibodies are detectable in $45 \%-90 \%$ of adults [145]. The preexisting immunity directed against Ad5 is considered as a main reason of failure in the phase I clinical trial of a protective HIV-1 vaccine. STEP study guided by Merck pharmaceutical concern, based on 3-dose regimen of a trivalent Ad5 vaccine, suggested that the immunization might increase the risk of HIV-1 infection in the subjects with high neutralizing antiAd5 titers [146-148]. Moreover, even single immunization may induce immunity to the vector in seronegative individuals.

The negative effect of the pre-existing or Ad5-induced immunity against the vaccine, mostly when the therapy requires multiple dosages, may be overcome by heterologous prime-boost regimen. The utility of the rare human serotypes (e.g., serotype 35) [149, 150] or recombinant adenoviruses of nonhuman origin has been recently tested
[151]. In particular, subsequent priming immunizations with plasmid DNA vaccine followed by a booster vaccination with AdV seem to be a very promising strategy. DNA primeadenovirus boost regimen proved to induce more robust and potent immune response in comparison to plasmid DNA alone and provided protection against the pathogen challenge in several animal models of infectious diseases [149, 152-154]. Furthermore, a clinical trial of multiclade HIV-1 DNA plasmid-Ad5 boost vaccine, HIVuninfected individuals demonstrated high immunogenicity even in the presence of high anti-Ad5 antibody titer. In addition, the vaccine proved to be well tolerated in the participants of the study [155].

\section{Improvement of Adenoviral Vectors}

Several studies indicate that the transgene expression level can be increased from adenoviral vectors by the presence or insertion of an intron sequences [156-158]. Therefore, we constructed the new recombinant adenoviruses serotype 5 and 35 encoding WHV core protein and containing an intron between promoter and WHcAg gene sequences. Preliminary experiments showed that vaccination with the AdVs containing the intron sequences led to induction of robust cellular and humoral immune responses in mice. Moreover, immunization of the mice in DNA prime-AdV boost manner, using improved vectors, resulted in more vigorous and multispecific $\mathrm{T}$ cell responses in comparison to immunization with plasmid DNA alone [Kosinska et al., unpublished results].

Immunization of chronically WHV-infected woodchucks with plasmid DNA vaccine in combination with entecavir treatment showed a marked therapeutic effect. Addition of 
TABLE 3: Studies on gene therapy of chronic hepatitis and HCC in the woodchuck model.

\begin{tabular}{|c|c|c|c|}
\hline Vector & Application & Outcome & Reference \\
\hline $\begin{array}{l}\text { Helper-dependent AdV expressing } \\
\text { woodchuck IFN } \alpha\end{array}$ & $\begin{array}{l}\text { Intravenous (portal } \\
\text { vein) }\end{array}$ & Transient inhibition of WHV replication & Fiedler et al., 2004 [163] \\
\hline $\begin{array}{l}\text { Helper-dependent AdV expressing } \\
\text { woodchuck IFN } \gamma\end{array}$ & $\begin{array}{l}\text { Intravenous (portal } \\
\text { vein) }\end{array}$ & No effect & Fiedler et al., 2004 [163] \\
\hline \multirow{2}{*}{$\begin{array}{l}\text { AdV expressing woodchuck IFN } \gamma \text { in } \\
\text { combination with clevudine (L-FMAU) } \\
\text { and emtricitabine (FTC) }\end{array}$} & \multirow[t]{2}{*}{ intravenous } & $\begin{array}{l}\text { T-cell infiltration and inflammation in } \\
\text { the liver }\end{array}$ & \\
\hline & & $\begin{array}{l}\text { No additional antiviral effect beyond the } \\
\text { treatment with the nucleot(s)ide } \\
\text { analogues }\end{array}$ & Jacquard et al., 2004 [164] \\
\hline $\begin{array}{l}\text { AdV expressing woodchuck IFN } \gamma \text { and } \\
\text { TNF } \alpha \text { in combination with clevudine } \\
\text { (L-FMAU) }\end{array}$ & intravenous & Transient inhibition of WHV replication & Zhu et al., 2004 [165] \\
\hline \multirow{3}{*}{$\begin{array}{l}\text { High-capacity AdV expressing murine } \\
\text { IL-12 under the control of a liver-specific } \\
\text { inducible promoter }\end{array}$} & \multirow{3}{*}{$\begin{array}{l}\text { intrahepatic (via } \\
\text { laparotomy) }\end{array}$} & $\begin{array}{l}\text { Inhibition of WHV replication in the } \\
\text { liver and decreased viral load in serum. }\end{array}$ & \multirow{3}{*}{ Crettaz et al., 2009 [166] } \\
\hline & & Induction of anti-WHs antibodies. & \\
\hline & & $\begin{array}{l}\text { The effect was observed only in animals } \\
\text { with basal viremia lower than } 10^{10} \\
\text { copies } / \mathrm{mL} \text {. }\end{array}$ & \\
\hline \multirow{2}{*}{$\begin{array}{l}\text { AdV expressing herpes simplex virus } \\
\text { thimidine kinase combined with } \\
\text { gancyclovir treatment }\end{array}$} & \multirow[t]{2}{*}{$\begin{array}{l}\text { intratumoural (via } \\
\text { laparotomy) }\end{array}$} & $\begin{array}{l}\text { Necrotic areas in the tumour mass and in } \\
\text { the liver. }\end{array}$ & \multirow[t]{2}{*}{ Bilbao et al., 2000 [167] } \\
\hline & & No reduction in tumour volume. & \\
\hline \multirow[t]{2}{*}{$\begin{array}{l}\text { AdV expressing murine IL-12 and B7.1 } \\
\text { molecule }\end{array}$} & \multirow{2}{*}{$\begin{array}{l}\text { intratumoural (via } \\
\text { laparotomy and MRI } \\
\text { guidance) }\end{array}$} & $\begin{array}{l}\mathrm{CD} 4^{+} \text {and } \mathrm{CD} 8^{+} \mathrm{T} \text { cell infiltration in the } \\
\text { liver. }\end{array}$ & \multirow[t]{2}{*}{ Pützer et al., 2001 [168] } \\
\hline & & Reduction in tumour volume. & \\
\hline \multirow{3}{*}{$\begin{array}{l}\text { Semliki forest viral vector expressing } \\
\text { murine IL-12 }\end{array}$} & \multirow{3}{*}{$\begin{array}{l}\text { intratumoural (via } \\
\text { laparotomy) }\end{array}$} & $\begin{array}{l}\text { Induction of } \mathrm{T} \text { cell responses to tumour } \\
\text { antigens. }\end{array}$ & \multirow{3}{*}{$\begin{array}{l}\text { Rodriguez-Madoz et al., } \\
2009 \text { [75] }\end{array}$} \\
\hline & & $\begin{array}{l}\text { Induction } \mathrm{T} \text { cell responses to WHcAg and } \\
\text { WHsAg. }\end{array}$ & \\
\hline & & $\begin{array}{l}\text { Dose-dependent, transient reduction in } \\
\text { tumour volume. }\end{array}$ & \\
\hline
\end{tabular}

the recombinant adenoviruses to this regimen could be a new, more potent approach in treatment of chronic hepatitis B. We will apply DNA prime-AdV boost approach in WHV chronically infected woodchucks in combination with nucleos(t)ide analogs and evaluate its therapeutic potential.

\section{Adenoviral Vectors for Gene Transfer Strategies in Treatment of Chronic Hepatitis B}

Over the last 20 years, modified adenoviruses have been extensively studied as a vehicle for gene delivery to the liver, because of their high transfection efficiency and their natural tropism for hepatocytes [159, 160]. Moreover, the development of the third generation of adenoviral vectors that lack all viral coding sequences (e.g., helper-dependent adenoviral vectors), resulted in their increased capacity and minimized immunogenicity of the vector allowing longterm transgene expression [161]. High cloning capacity of those vectors enables usage of inducible or tissue-specific promoters and coexpression of multiple therapeutic or immunomodulatory genes [162].
So far, several trials of virus-mediated gene therapy for treatment of chronic hepatitis and HCC were performed in chronically WHV-infected woodchucks and in cell culture systems. Those strategies were mainly based on delivery of antiviral cytokines, such as IFN $\alpha$, IFN $\gamma$, IL-12 by recombinant adenoviruses, to reduce viral replication or modulate the immune response (Table 3 ).

Transduction of primary woodchuck hepatocytes from chronic WHV carriers with helper-dependent AdV encoding woodchuck IFN $\alpha(w I F N \alpha)$ resulted in the reduction of WHV proteins expression in vitro [169]. In vivo studies on chronically WHV-infected woodchucks, demonstrated that a single injection of $1 \times 10^{12} \mathrm{vp}$ of this vector into the liver's portal vein could inhibit WHV replication by $1 \log$ up to 11 weeks after the treatment [163]. The same approach with helper-dependent AdV expressing woodchuck IFN $\gamma($ wIFN $\gamma)$ did not show any antiviral effect, even though the transduction led to the production of biologically active interferon [163]. Another study combined intravenous delivery wIFN $\gamma$ by recombinant adenoviral vector with nucleos(t)ide analogues therapy. Chronic WHV carriers were treated with clevudine and emtricitabine (FTC), together, for 8 weeks and after the initial drop in viral load one group of 
animals received additionally two i.v. injections of $3 \times 10^{10}$ PFU of Ad-IFN $\gamma$. Delivery of wIFN $\gamma$ induced inflammation, caused by $\mathrm{T}$ cell infiltration, and increased hepatocyte turnover. However, this effect did not induce additional antiviral outcome in comparison clevudine/emtricitabine biotherapy alone [164]. Similarly, poor therapeutic effect was observed for gene therapy based on both wIFN $\gamma$ and wTNF $\alpha$. Intravenous injection of those recombinant adenoviruses during clevudine treatment led to decrease of replicative intermediates of WHV DNA in the liver, beyond what could be achieved by clevudine alone. Nevertheless, 6 weeks after injection there was no significant difference between the groups of WHV carriers receiving AdV expressing the cytokines or beta-galactosidase as a control [165]. The benefits of using the immunomodulatory genes in this study are difficult to assess, since it was reported that adenovirus infection alone is sufficient to transiently suppress the WHV replication in chronically infected woodchucks [170]. The lack of therapeutic effect by direct delivery of IFN $\gamma$ is consistent with in vitro data obtained from persistentlyinfected woodchuck primary hepatocytes. Treatment of the cells with wIFN $\gamma$, even in the presence of ${ }_{\operatorname{TNNF}} \alpha$, was not able to inhibit the WHV replication. Moreover, high concentration of those cytokines resulted in the loss of the cells during the culture [171]. This observation underlines the cytotoxic effect of Th1 cytokines on the woodchuck hepatocytes. Rapid downregulation of the IFN $\gamma$ expression, after transduction of the liver cells with viral vector, could be one of the mechanisms to protect the organism from the potential toxicity of this cytokine in vivo [163]. In addition, several reports indicates that the level of wIFN $\gamma$ and ${ }^{\mathrm{wTNF}} \alpha$ is higher in the liver of chronic WHV carriers in comparison to naïve animals $[172,173]$. Therefore, continuous presence of inflammatory cytokines in the liver during the chronic WHV infection could result in hyporesponsiveness of hepatocytes to such a therapy.

The novel strategy to treat chronic WHV hepatitis is based on adenovirus-mediated delivery of murine IL-12 (mIL-12) gene into hepatocytes [166]. Interleukin-12 is a proinflammatory cytokine produced naturally by antigen presenting cells. IL-12 stimulates production of IFN $\gamma$ and TNF $\alpha$ by $\mathrm{T}$ and natural killer (NK) cells and enhances their cytotoxic activity [174]. In the study, mIL-12 gene expression could be regulated by inducible promoter that was responding to progesterone antagonist RU486. Eight chronic WHV carriers received single dose of $2 \times 10^{10}$ i.u. of AdV expressing mIL-12 (HC-Ad/RUmIL-12) by intrahepatic injection at laparotomy. Two weeks after, the expression of mIL-12 was induced by the administration of RU486. The IL12 treatment resulted in intense and sustained suppression of WHV replication in the liver as well as decreased viral loads in the serum. This effect, however, was visible only in the animals with basal viremia lower than $10^{10}$ WHV copies per milliliter of serum. Animals, which responded to the therapy, developed a vigorous $\mathrm{T}$ cell response to WHcAg, measured by woodchuck IL-2 production, and demonstrated WHeAg and WHsAg seroconversion. Moreover, the FoxP3 levels in the livers of those animals were decreased, while in nonresponder woodchucks FoxP3 values were significantly upregulated [166]. This finding suggests that the intrahepatic expression of IL-12 may inhibit the regulatory T cells in the liver during the chronic WHV infection. Indirect induction of inflammatory cytokines, such as IFN $\gamma$ and TNF $\alpha$ by IL-12, seems to be a more efficient strategy in breaking the tolerance to virus antigens than direct delivery of those cytokines. It suggests that probably additional events occur in the liver after AdV-mediated IL-12 transfer that supports the antiviral effects of this therapy.

\section{Gene Transfer Strategies for the Treatment of Hepatocellular Carcinoma}

Adenoviral delivery of genes for cytokines and other immunomodulators is widely used in cancer therapy in the animal tumor models as well as in patients [137, 175-178]. The $\mathrm{T}$ cells play an important role not only in defense against the pathogens, but also in antitumor immunity and inhibition of the tumor growth. Interleukin-12 inhibits the angiogenesis and induces a potent antitumoral immune response by stimulation of IFN $\gamma$ secretion. Therefore, IL-12 is a promising candidate for cancer gene therapy [179-183]. Strategy based on recombinant adenoviruses expressing IL12 demonstrated antitumor effect in the murine models with transplantable HCC $[184,185]$ and was also evaluated in woodchucks [168].

In the study, large $(2-5 \mathrm{~cm})$ intrahepatic tumors of 5 woodchucks were injected with a single dose of $1 \times$ $10^{9}$ PFU AdV expressing IL-12 and B7.1 molecule (AdIL12/B7.1). The B7.1 molecule (also known as a CD80) is naturally expressed on the professional APCs and provides the synergistic effect in the tumor regression [181, 186, 187]. In 4 out of 5 animals, AdIL-12/B7.1 was delivered by laparotomy into the three HCC nodules and three nodules were injected with a vector expressing GFP as a control. Animals were sacrificed 7-14 days later and the tumor volumes were assessed. On average, treated tumors showed an $80 \%$ reduction in the volume whereas the size of the AdGFP-injected nodules increased. Remission of the tumors was associated with $\mathrm{CD}^{+}$and $\mathrm{CD}^{+} \mathrm{T}$ cell infiltration into the tumor tissue and increased local IFN $\gamma$ levels after AdIL-12/B7.1 injection. One of the treated woodchucks received the intratumoral injection by magnetic resonance imaging (MRI) guidance and was monitored for 7 weeks. During this period the tumor size decreased from $8,6 \mathrm{~cm}^{3}$ to $0,5 \mathrm{~cm}^{3}$ [168]. This observation shows that administration of AdIL-12/B7.1 during MRI guidance, with therapeutic effect similar to laparotomy, could prevent the animals from harmful consequences of the surgery.

The study proved that the gene therapy based on IL-12 leads may be a promising strategy to treat HCC. By contrast, treatment with AdV encoding herpes simplex thymidine kinase combined with gancclovir administration did not lead to reduction in the tumor size [167]. Nevertheless, the short time of monitoring during the study makes it difficult to evaluate the prolonged antitumoral effect of this approach.

A recent study presents gene therapy with semliki forest viral vector expressing high levels of murine IL12 (SFV-enhIL-12) on remission of HCC in chronically 
WHV-infected woodchucks. In the research, the vector was delivered by surgery into multiple sites of HCC tumors in the liver [75]. A total of nine woodchucks were enrolled in the experiment. Six of the woodchucks, two animals each, received different doses of SFV-enhIL-12: $3 \times 10^{9} \mathrm{vp}, 6 \times$ $10^{9} \mathrm{vp}$, and $1,2 \times 10^{10} \mathrm{vp}$, and three animals served as a control and received saline injections. The tumor size was monitored by ultrasound examination for 23 to 24 weeks. In all woodchucks, reduction in tumor volume was observed, however, this effect was transient and dose dependent. Animals treated with the highest dose of SFV-enhIL-12 showed the most spectacular reduction of the tumor size $71 \%$ and $80 \%$. Nevertheless, the tumors started to grow between 6 and 14 weeks after the treatment. The antitumoral effect was associated with the induction of the immune response towards the tumor antigens, demonstrated by $\mathrm{T}$ cell proliferation assay, upregulation of leukocyte markers expression, and cytokine production, such as IFN $\gamma, \operatorname{TNF} \alpha$, IL-6, and IL-12. In addition, the therapy resulted in transient induction of lymphoproliferative responses against WHcAg and WHsAg and led to short-term reduction in WHV viral load [75].

The results presented here indicate that viral-mediated gene therapy in treatment of chronic hepatitis $\mathrm{B}$ and HCC needs further optimization. However, treatment of the woodchucks with viral vectors allowed to achieve a long-lasting expression of the cytokines and their higher concentration preferably in the liver. Therefore, this strategy is proven to be more effective than an approach based on using of the soluble cytokines. In addition, adenovirusmediated gene transfer is proven to be a safe and a welltolerated strategy in the woodchucks.

\section{Conclusion}

The current progress indicates the feasibility of therapeutic approaches for treatment of chronic HBV infection. There is a general agreement that a combination of antiviral treatment and immunomodulation is essential to achieve a sustained control of HBV infection. However, many scientific questions are still not answered. The question how HBV infection leads to defective immune responses to HBV proteins remains to be investigated. This issue is the key to a more rational design of new therapeutic approaches. Recently, HBV proteins were found to suppress host innate responses [188]. It has to be clarified whether an early blockage of innate immune responses may further negatively influence the priming of adaptive immune responses. In addition, different groups reported consistently that TLR2 and TLR4 signalling may be impaired in chronic HBV infection patients $[189,190]$. Thus, it is worthy to test whether an enhancement of innate immune responses in chronic carriers is necessary for restoration of specific immune responses. With the increasing number of available vaccine formulation, a more crucial question raised recently: what is the optimal combination of these vaccines. Obviously, it is necessary to test the mutual influences of different types of vaccines to maximize their effects and avoid the negative interference between the vaccines. Finally, the future design of therapeutic vaccines needs to be considered in nonnaïve hosts since patients have undergone other infections. It is yet not possible to foresee how the pre-existing infections and immunological backgrounds will influence the effect of therapeutic vaccines. Understanding these issues will be helpful for the translation of recent progresses for clinical use of therapeutic vaccines.

\section{References}

[1] M. Peters, J. Vierling, M. E. Gershwin, D. Milich, F. V. Chisari, and J. H. Hoofnagle, "Immunology and the liver," Hepatology, vol. 13, no. 5, pp. 977-994, 1991.

[2] H. S. Conjeevaram and A. S.-F. Lok, "Management of chronic hepatitis B," Journal of Hepatology, Supplement, vol. 38, no. 1, pp. S90-S103, 2003.

[3] H. L. A. Janssen, M. Van Zonneveld, H. Senturk et al., "Pegylated interferon alfa-2b alone or in combination with lamivudine for HBeAg-positive chronic hepatitis B: a randomised trial," The Lancet, vol. 365, no. 9454, pp. 123-129, 2005.

[4] G. K. K. Lau, T. Piratvisuth, K. X. Luo et al., "Peginterferon Alfa-2a, lamivudine, and the combination for HBeAgpositive chronic hepatitis B," The New England Journal of Medicine, vol. 352, no. 26, pp. 2682-2695, 2005.

[5] J. L. Dienstag, "Drug therapy: hepatitis B virus infection," The New England Journal of Medicine, vol. 359, no. 14, pp. 14861500, 2008.

[6] A. K. Raney, R. K. Hamatake, and Z. Hong, "Agents in clinical development for the treatment of chronic hepatitis B," Expert Opinion on Investigational Drugs, vol. 12, no. 8, pp. 12811295, 2003.

[7] S. Locarnini and W. S. Mason, "Cellular and virological mechanisms of HBV drug resistance," Journal of Hepatology, vol. 44, no. 2, pp. 422-431, 2006.

[8] A. Penna, M. Artini, A. Cavalli et al., "Long-lasting memory $\mathrm{T}$ cell responses following self-limited acute hepatitis B," Journal of Clinical Investigation, vol. 98, no. 5, pp. 1185-1194, 1996.

[9] A. Penna, G. Del Prete, A. Cavalli et al., "Predominant Thelper 1 cytokine profile of hepatitis B virus nucleocapsidspecific T cells in acute self-limited hepatitis B," Hepatology, vol. 25, no. 4, pp. 1022-1027, 1997.

[10] L. G. Guidotti, R. Rochford, J. Chung, M. Shapiro, R. Purcell, and F. V. Chisari, "Viral clearance without destruction of infected cells during acute HBV infection," Science, vol. 284, no. 5415 , pp. 825-829, 1999.

[11] R. Thimme, S. Wieland, C. Steiger et al., "CD8 ${ }^{+} \mathrm{T}$ cells mediate viral clearance and disease pathogenesis during acute hepatitis B virus infection," Journal of Virology, vol. 77, no. 1, pp. 68-76, 2003.

[12] M. K. Maini, C. Boni, C. K. Lee et al., "The role of virusspecific $\mathrm{CD}^{+}$cells in liver damage and viral control during persistent hepatitis B virus infection," Journal of Experimental Medicine, vol. 191, no. 8, pp. 1269-1280, 2000.

[13] J. A. Trapani and M. J. Smyth, "Functional significance of the perforin/granzyme cell death pathway," Nature Reviews Immunology, vol. 2, no. 10, pp. 735-747, 2002.

[14] L. G. Guidotti, T. Ishikawa, M. V. Hobbs, B. Matzke, R. Schreiber, and F. V. Chisari, "Intracellular inactivation of the hepatitis B virus by cytotoxic T lymphocytes," Immunity, vol. 4, no. 1, pp. 25-36, 1996. 
[15] H. Mcclary, R. Koch, F. V. Chisari, and L. G. Guidotti, "Relative sensitivity of hepatitis B virus and other hepatotropic viruses to the antiviral effects of cytokines," Journal of Virology, vol. 74, no. 5, pp. 2255-2264, 2000.

[16] S. F. Wieland, L. G. Guidotti, and F. V. Chisari, "Intrahepatic induction of alpha/beta interferon eliminates viral RNAcontaining capsids in hepatitis B virus transgenic mice," Journal of Virology, vol. 74, no. 9, pp. 4165-4173, 2000.

[17] M. C. Jung, U. Spengler, W. Schraut et al., "Hepatitis B virus antigenspecific T-cell activation in patients with acute and chronic hepatitis B," Journal of Hepatology, vol. 13, no. 3, pp. 310-317, 1991.

[18] A. Penna, F. V. Chisari, A. Bertoletti et al., "Cytotoxic T lymphocytes recognize an HLA-A2-restricted epitope within the hepatitis B virus nucleocapsid antigen," Journal of Experimental Medicine, vol. 174, no. 6, pp. 1565-1570, 1991.

[19] B. Rehermann, "Immune responses in hepatitis B virus infection," Seminars in Liver Disease, vol. 23, no. 1, pp. 21$38,2003$.

[20] B. Rehermann and M. Nascimbeni, "Immunology of hepatitis B virus and hepatitis C virus infection," Nature Reviews Immunology, vol. 5, no. 3, pp. 215-229, 2005.

[21] P. L. Yang, A. Althage, J. Chung et al., "Immune effectors required for hepatitis B virus clearance," Proceedings of the National Academy of Sciences of the United States of America, vol. 107, no. 2, pp. 798-802, 2010.

[22] F. V. Chisari and C. Ferrari, "Hepatitis B virus immunopathogenesis," Annual Review of Immunology, vol. 13, pp. 29-60, 1995.

[23] G. J. M. Webster, S. Reignat, D. Brown et al., "Longitudinal analysis of $\mathrm{CD}^{+} \mathrm{T}$ cells specific for structural and nonstructural hepatitis B virus proteins in patients with chronic hepatitis B: implications for immunotherapy," Journal of Virology, vol. 78, no. 11, pp. 5707-5719, 2004.

[24] T. Okazaki and T. Honjo, "The PD-1-PD-L pathway in immunological tolerance," Trends in Immunology, vol. 27, no. 4, pp. 195-201, 2006.

[25] E. J. Wherry, S.-J. Ha, S. M. Kaech et al., "Molecular signature of $\mathrm{CD}^{+} \mathrm{T}$ cell exhaustion during chronic viral infection," Immunity, vol. 27, no. 4, pp. 670-684, 2007.

[26] S. Urbani, B. Amadei, D. Tola et al., "PD-1 expression in acute hepatitis $\mathrm{C}$ virus (HCV) infection is associated with $\mathrm{HCV}$ specific CD8 exhaustion," Journal of Virology, vol. 80, no. 22, pp. 11398-11403, 2006.

[27] S. Urbani, B. Amadei, D. Tola et al., "Restoration of HCVspecific $\mathrm{T}$ cell functions by PD-1/PD-L1 blockade in HCV infection: effect of viremia levels and antiviral treatment," Journal of Hepatology, vol. 48, no. 4, pp. 548-558, 2008.

[28] C. L. Day, D. E. Kaufmann, P. Kiepiela et al., "PD-1 expression on HIV-specific T cells is associated with T-cell exhaustion and disease progression," Nature, vol. 443, no. 7109, pp. 350354, 2006.

[29] C. Petrovas, J. P. Casazza, J. M. Brenchley et al., "PD-1 is a regulator of virus-specific $\mathrm{CD}^{+} \mathrm{T}$ cell survival in HIV infection," Journal of Experimental Medicine, vol. 203, no. 10, pp. 2281-2292, 2006.

[30] L. Trautmann, L. Janbazian, N. Chomont et al., "Upregulation of PD- 1 expression on HIV-specific CD8 ${ }^{+} \mathrm{T}$ cells leads to reversible immune dysfunction," Nature Medicine, vol. 12, no. 10, pp. 1198-1202, 2006.

[31] D. L. Barber, E. J. Wherry, D. Masopust et al., "Restoring function in exhausted CD8 $\mathrm{T}$ cells during chronic viral infection," Nature, vol. 439, no. 7077, pp. 682-687, 2006.
[32] A. Grakoui, E. J. Wherry, H. L. Hanson, C. Walker, and R. Ahmed, "Turning on the off switch: regulation of anti-viral $\mathrm{T}$ cell responses in the liver by the PD-1/PD-L1 pathway," Journal of Hepatology, vol. 45, no. 4, pp. 468-472, 2006.

[33] C. Boni, P. Fisicaro, C. Valdatta et al., "Characterization of hepatitis B virus (HBV)-specific T-cell dysfunction in chronic HBV infection," Journal of Virology, vol. 81, no. 8, pp. 4215-4225, 2007.

[34] H. Maier, M. Isogawa, G. J. Freeman, and F. V. Chisari, "PD-1:PD-L1 interactions contribute to the functional suppression of virus-specific CD8 ${ }^{+} \mathrm{T}$ lymphocytes in the liver," Journal of Immunology, vol. 178, no. 5, pp. 2714-2720, 2007.

[35] R. G. Van Der Molen, D. Sprengers, R. S. Binda et al., "Functional impairment of myeloid and plasmacytoid dendritic cells of patients with chronic hepatitis B," Hepatology, vol. 40, no. 3, pp. 738-746, 2004.

[36] M. Miyazaki, T. Kanto, M. Inoue et al., "Impaired cytokine response in myeloid dendritic cells in chronic hepatitis $\mathrm{C}$ virus infection regardless of enhanced expression of tolllike receptors and retinoic acid inducible gene-I," Journal of Medical Virology, vol. 80, no. 6, pp. 980-988, 2008.

[37] S. Tavakoli, I. Mederacke, S. Herzog-Hauff et al., "Peripheral blood dendritic cells are phenotypically and functionally intact in chronic hepatitis B virus (HBV) infection," Clinical and Experimental Immunology, vol. 151, no. 1, pp. 61-70, 2008.

[38] K. Wang, X. Fan, Y. Fan, B. Wang, L. Han, and Y. Hou, "Study on the function of circulating plasmacytoid dendritic cells in the immunoactive phase of patients with chronic genotype B and C HBV infection," Journal of Viral Hepatitis, vol. 14, no. 4, pp. 276-282, 2007.

[39] L. Chen, Z. Zhang, W. Chen et al., "B7-H1 up-regulation on myeloid dendritic cells significantly suppresses $\mathrm{T}$ cell immune function in patients with chronic hepatitis B," Journal of Immunology, vol. 178, no. 10, pp. 6634-6641, 2007.

[40] B. J. Zheng, J. Zhou, D. Qu et al., "Selective functional deficit in dendritic cell - T cell interaction is a crucial mechanism in chronic hepatitis B virus infection," Journal of Viral Hepatitis, vol. 11, no. 3, pp. 217-224, 2004.

[41] J. Hong and Z. J. Gong, "Human plasmacytoid dendritic cells from patients with chronic hepatitis B virus infection induce the generation of a higher proportion of $\mathrm{CD}_{4}^{+}$and $\mathrm{CD} 25^{+}$regulatory T cells compared with healthy patients," Hepatology Research, vol. 38, no. 4, pp. 362-373, 2008.

[42] S. Li, E. J. Gowans, C. Chougnet, M. Plebanski, and U. Dittmer, "Natural regulatory $\mathrm{T}$ cells and persistent viral infection," Journal of Virology, vol. 82, no. 1, pp. 21-30, 2008.

[43] S. M. Rushbrook, S. M. Ward, E. Unitt et al., "Regulatory T cells suppress in vitro proliferation of virus-specific $\mathrm{CD}^{+} \mathrm{T}$ cells during persistent hepatitis C virus infection," Journal of Virology, vol. 79, no. 12, pp. 7852-7859, 2005.

[44] A. L. Kinter, M. Hennessey, A. Bell et al., "CD25 ${ }^{+} \mathrm{CD} 4^{+}$ regulatory $\mathrm{T}$ cells from the peripheral blood of asymptomatic HIV-infected individuals regulate $\mathrm{CD}^{+}$and $\mathrm{CD}^{+} \mathrm{HIV}$ specific $\mathrm{T}$ cell immune responses in vitro and are associated with favorable clinical markers of disease status," Journal of Experimental Medicine, vol. 200, no. 3, pp. 331-343, 2004.

[45] L. Weiss, V. Donkova-Petrini, L. Caccavelli, M. Balbo, C. Carbonneil, and Y. Levy, "Human immunodeficiency virusdriven expansion of $\mathrm{CD} 4{ }^{+} \mathrm{CD} 25^{+}$regulatory $\mathrm{T}$ cells, which suppress HIV-specific CD4 T-cell responses in HIV-infected patients," Blood, vol. 104, no. 10, pp. 3249-3256, 2004.

[46] D. Xu, J. Fu, L. Jin et al., "Circulating and liver resident $\mathrm{CD} 4{ }^{+} \mathrm{CD} 25^{+}$regulatory $\mathrm{T}$ cells actively influence the antiviral 
immune response and disease progression in patients with hepatitis B," Journal of Immunology, vol. 177, no. 1, pp. 739747, 2006.

[47] P. Bertolino, D. G. Bowen, G. W. McCaughan, and B. Fazekas de St. Groth, "Antigen-specific primary activation of CD8 ${ }^{+} \mathrm{T}$ cells within the liver," Journal of Immunology, vol. 166, no. 9, pp. 5430-5438, 2001.

[48] D. G. Bowen, M. Zen, L. Holz, T. Davis, G. W. McCaughan, and P. Bertolino, "The site of primary $\mathrm{T}$ cell activation is a determinant of the balance between intrahepatic tolerance and immunity," Journal of Clinical Investigation, vol. 114, no. 5, pp. 701-712, 2004.

[49] Z. L. Brumme, C. J. Brumme, D. Heckerman et al., "Evidence of differential HLA class I-mediated viral evolution in functional and accessory/regulatory genes of HIV-1," PLoS Pathogens, vol. 3, no. 7, article e94, pp. 0913-0927, 2007.

[50] T. Bhattacharya, M. Daniels, D. Heckerman et al., "Founder effects in the assessment of HIV polymorphisms and HLA allele associations," Science, vol. 315 , no. 5818, pp. 15831586, 2007.

[51] J. Timm, B. Li, M. G. Daniels et al., "Human leukocyte antigen-associated sequence polymorphisms in hepatitis C virus reveal reproducible immune responses and constraints on viral evolution," Hepatology, vol. 46, no. 2, pp. 339-349, 2007.

[52] Z.-Y. Keck, S. H. Li, J. Xia et al., "Mutations in hepatitis C virus E2 located outside the CD81 binding sites lead to escape from broadly neutralizing antibodies but compromise virus infectivity," Journal of Virology, vol. 83, no. 12, pp. 61496160, 2009.

[53] C.-J. Liu, J.-H. Kao, W.-Y. Shau, P.-J. Chen, M.-Y. Lai, and D.-S. Chen, "Naturally occurring hepatitis B surface gene variants in chronic hepatitis B virus infection: correlation with viral serotypes and clinical stages of liver disease," Journal of Medical Virology, vol. 68, no. 1, pp. 50-59, 2002.

[54] Y.-H. Ni, M.-H. Chang, H.-Y. Hsu et al., "Mutations of T-cell epitopes in the hepatitis B virus surface gene in children with chronic infection and hepatocellular carcinoma," American Journal of Gastroenterology, vol. 103, no. 4, pp. 1004-1009, 2008.

[55] C. Boni, A. Penna, G. S. Ogg et al., "Lamivudine treatment can overcome cytotoxic T-cell hyporesponsiveness in chronic hepatitis B: new perspectives for immune therapy," Hepatology, vol. 33, no. 4, pp. 963-971, 2001.

[56] C. Boni, A. Penna, A. Bertoletti et al., "Transient restoration of anti-viral $\mathrm{T}$ cell responses induced by lamivudine therapy in chronic hepatitis B," Journal of Hepatology, vol. 39, no. 4, pp. 595-605, 2003.

[57] E. I. Rigopoulou, D. Suri, S. Chokshi et al., "Lamivudine plus interleukin-12 combination therapy in chronic hepatitis B: antiviral and immunological activity," Hepatology, vol. 42, no. 5, pp. 1028-1036, 2005.

[58] S. Pol, F. Driss, M.-L. Michel, B. Nalpas, P. Berthelot, and C. Brechot, "Specific vaccine therapy in chronic hepatitis B infection," The Lancet, vol. 344, no. 8918, p. 342, 1994.

[59] S. Pol, B. Nalpas, F. Driss et al., "Efficacy and limitations of a specific immunotherapy in chronic hepatitis B," Journal of Hepatology, vol. 34, no. 6, pp. 917-921, 2001.

[60] I. Couillin, S. Pol, M. Mancini et al., "Specific vaccine therapy in chronic hepatitis B: induction of $\mathrm{T}$ cell proliferative responses specific for envelope antigens," Journal of Infectious Diseases, vol. 180, no. 1, pp. 15-26, 1999.

[61] M.-C. Jung, N. Grüner, R. Zachoval et al., "Immunological monitoring during therapeutic vaccination as a prerequisite for the design of new effective therapies: induction of a vaccine-specific $\mathrm{CD} 4{ }^{+} \mathrm{T}$-cell proliferative response in chronic hepatitis B carriers," Vaccine, vol. 20, no. 29-30, pp. 35983612, 2002.

[62] F. Ren, K. Hino, Y. Yamaguchi et al., "Cytokine-dependent anti-viral role of $\mathrm{CD}^{+}$-positive $\mathrm{T}$ cells in therapeutic vaccination against chronic hepatitis B viral infection," Journal of Medical Virology, vol. 71, no. 3, pp. 376-384, 2003.

[63] R. Safadi, E. Israeli, O. Papo et al., "Treatment of chronic hepatitis B virus infection via oral immune regulation toward hepatitis B virus proteins," American Journal of Gastroenterology, vol. 98, no. 11, pp. 2505-2515, 2003.

[64] K. Yalcin, M. Acar, and H. Degertekin, "Specific hepatitis B vaccine therapy in inactive HBsAg carriers: a randomized controlled trial," Infection, vol. 31, no. 4, pp. 221-225, 2003.

[65] B. Dikici, A. G. Kalayci, F. Ozgenc et al., "Therapeutic vaccination in the immunotolerant phase of children with chronic hepatitis B infection," Pediatric Infectious Disease Journal, vol. 22, no. 4, pp. 345-349, 2003.

[66] A. Dahmen, S. Herzog-Hauff, W. O. Bocher, et al., "Clinical and immunological efficacy of intradermal vaccine plus lamivudine with or without interleukin-2 in patients with chronic hepatitis B," Journal of Medical Virology, vol. 66, no. 4, pp. 452-460, 2002.

[67] N. Horiike, S. M. Fazle, K. Michitaka et al., "In vivo immunization by vaccine therapy following virus suppression by lamivudine: a novel approach for treating patients with chronic hepatitis B," Journal of Clinical Virology, vol. 32, no. 2, pp. 156-161, 2005.

[68] P. Vandepapelière, G. K. K. Lau, G. Leroux-Roels et al., "Therapeutic vaccination of chronic hepatitis B patients with virus suppression by antiviral therapy: a randomized, controlled study of co-administration of $\mathrm{HBsAg} / \mathrm{ASO} 2$ candidate vaccine and lamivudine," Vaccine, vol. 25, no. 51, pp. 85858597, 2007.

[69] J. Heathcote, J. McHutchison, S. Lee et al., "A pilot study of the CY-1899 T-cell vaccine in subjects chronically infected with hepatitis B virus," Hepatology, vol. 30, no. 2, pp. 531536, 1999.

[70] M. Mancini-Bourgine, H. Fontaine, D. Scott-Algara, S. Pol, C. Bréchot, and M.-L. Michel, "Induction or expansion of Tcell responses by a hepatitis B DNA vaccine administered to chronic HBV carriers," Hepatology, vol. 40, no. 4, pp. 874882, 2004.

[71] S.-H. Yang, C.-G. Lee, S.-H. Park et al., "Correlation of antiviral T-cell responses with suppression of viral rebound in chronic hepatitis B carriers: a proof-of-concept study," Gene Therapy, vol. 13, no. 14, pp. 1110-1117, 2006.

[72] S. Menne, J. Maschke, M. Lu, H. Grosse-Wilde, and M. Roggendorf, "T-cell response to woodchuck hepatitis virus (WHV) antigens during acute self-limited WHV infection and convalescence and after viral challenge," Journal of Virology, vol. 72, no. 7, pp. 6083-6091, 1998.

[73] I. Frank, C. Budde, M. Fiedler et al., "Acute resolving woodchuck hepatitis virus (WHV) infection is associated with a strong cytotoxic T-lymphocyte response to a single WHV core peptide," Journal of Virology, vol. 81, no. 13, pp. 7156-7163, 2007.

[74] S. Menne, C. A. Roneker, B. E. Korba, J. L. Gerin, B. C. Tennant, and P. J. Cote, "Immunization with surface antigen vaccine alone and after treatment with 1-(2-fluoro-5-methyl$\beta$-L-arabinofuranosyl)-uracil (L-FMAU) breaks humoral and cell-mediated immune tolerance in chronic woodchuck 
hepatitis virus infection," Journal of Virology, vol. 76, no. 11, pp. 5305-5314, 2002.

[75] J. R. Rodriguez-Madoz, K. H. Liu, J. I. Quetglas et al., "Semliki forest virus expressing interleukin-12 induces antiviral and antitumoral responses in woodchucks with chronic viral hepatitis and hepatocellular carcinoma," Journal of Virology, vol. 83, no. 23, pp. 12266-12278, 2009.

[76] A. Vitiello, G. Ishioka, H. M. Grey et al., "Development of a lipopeptide-based therapeutic vaccine to treat chronic HBV infection. I. Induction of a primary cytotoxic T lymphocyte response in humans," Journal of Clinical Investigation, vol. 95, no. 1, pp. 341-349, 1995.

[77] Y.-M. Wen, X.-H. Wu, D.-C. Hu, Q.-P. Zhang, and S.-Q. Guo, "Hepatitis B vaccine and anti-HBs complex as approach for vaccine therapy," The Lancet, vol. 345, no. 8964, pp. 15751576, 1995.

[78] X. Yao, B. Zheng, J. Zhou et al., "Therapeutic effect of hepatitis B surface antigen-antibody complex is associated with cytolytic and non-cytolytic immune responses in hepatitis B patients," Vaccine, vol. 25, no. 10, pp. 1771-1779, 2007.

[79] D.-Z. Xu, K. Zhao, L.-M. Guo et al., "A randomized controlled phase IIb trial of antigen-antibody immunogenic complex therapeutic vaccine in chronic hepatitis B patients," PLoS ONE, vol. 3, no. 7, Article ID e2565, 2008.

[80] H. L. Davis, C. L. Brazolot Millan, M. Mancini et al., "DNAbased immunization against hepatitis B surface antigen (HBsAg) in normal and HBsAg-transgenic mice," Vaccine, vol. 15, no. 8, pp. 849-852, 1997.

[81] M. Mancini, M. Hadchouel, P. Tiollais, and M.-L. Michel, "Regulation of hepatitis B virus mRNA expression in a hepatitis B surface antigen transgenic mouse model by IFN$\gamma$-secreting T cells after DNA-based immunization," Journal of Immunology, vol. 161, no. 10, pp. 5564-5570, 1998.

[82] A. D. Sette, C. Oseroff, J. Sidney et al., "Overcoming T cell tolerance to the hepatitis B virus surface antigen in hepatitis B virus-transgenic mice," Journal of Immunology, vol. 166, no. 2, pp. 1389-1397, 2001.

[83] P. Riedl, A. Wieland, K. Lamberth et al., "Elimination of immunodominant epitopes from multispecific DNA-based vaccines allows induction of CD8 $\mathrm{T}$ cells that have a striking antiviral potential," Journal of Immunology, vol. 183, no. 1, pp. 370-380, 2009.

[84] M. Isogawa, Y. Furuichi, and F. V. Chisari, "Oscillating CD8 ${ }^{+}$ T cell effector functions after antigen recognition in the liver," Immunity, vol. 23, no. 1, pp. 53-63, 2005.

[85] M. Isogawa, M. D. Robek, Y. Furuichi, and F. V. Chisari, “Tolllike receptor signaling inhibits hepatitis B virus replication in vivo," Journal of Virology, vol. 79, no. 11, pp. 7269-7272, 2005.

[86] S. L. Uprichard, B. Boyd, A. Althage, and F. V. Chisari, "Clearance of hepatitis B virus from the liver of transgenic mice by short hairpin RNAs," Proceedings of the National Academy of Sciences of the United States of America, vol. 102, no. 3, pp. 773-778, 2005.

[87] K. Kimura, K. Kakimi, S. Wieland, L. G. Guidotti, and F. V. Chisari, "Activated intrahepatic antigen-presenting cells inhibit hepatitis B virus replication in the liver of transgenic mice," Journal of Immunology, vol. 169, no. 9, pp. 5188-5195, 2002.

[88] S. Wirth, L. G. Guidotti, K. Ando, H.-J. Schlicht, and F. V. Chisari, "Breaking tolerance leads to autoantibody production but not autoimmune liver disease in hepatitis B virus envelope transgenic mice," Journal of Immunology, vol. 154, no. 5, pp. 2504-2515, 1995.

[89] J. Summers, J. M. Smolec, and R. Snyder, "A virus similar to human hepatitis B virus associated with hepatitis and hepatoma in woodchucks," Proceedings of the National Academy of Sciences of the United States of America, vol. 75, no. 9, pp. 4533-4537, 1978.

[90] Q. Di, J. Summers, J. B. Burch, and W. S. Mason, "Major differences between WHV and HBV in the regulation of transcription," Virology, vol. 229, no. 1, pp. 25-35, 1997.

[91] S. Menne and P. J. Cote, "The woodchuck as an animal model for pathogenesis and therapy of chronic hepatitits B virus infection," World Journal of Gastroenterology, vol. 13, no. 1, pp. 104-124, 2007.

[92] P. J. Cote, B. E. Korba, R. H. Miller et al., "Effects of age and viral determinants on chronicity as an outcome of experimental woodchuck hepatitis virus injection," Hepatology, vol. 31, no. 1, pp. 190-200, 2000.

[93] H. Popper, L. Roth, and R. H. Purcell, "Hepatocarcinogenicity of the woodchuck hepatitis virus," Proceedings of the National Academy of Sciences of the United States of America, vol. 84, no. 3, pp. 866-870, 1987.

[94] B. C. Tennant, I. A. Toshkov, S. F. Peek et al., "Hepatocellular carcinoma in the woodchuck model of hepatitis B virus infection," Gastroenterology, vol. 127, pp. S283-S293, 2004.

[95] J. L. Gerin, P. J. Cote, B. E. Korba, et al., "Hepatitis B virus and liver cancer: the woodchuck as an experimental model of hepadnavirus-induced liver cancer," in Viral Hepatitis and Liver Disease, F. B. Hollinger, S. M. Lemon, and H. Margolis, Eds., pp. 556-559, Williams \& Wilkins, Baltimore, Md, USA, 1991.

[96] M. Roggendorf and T. K. Tolle, “The woodchuck: an animal model for hepatitis B virus infection in man," Intervirology, vol. 38, no. 1-2, pp. 100-112, 1995.

[97] B. E. Korba, P. J. Cote, and J. L. Gerin, "Mitogen-induced replication of Woodchuck hepatitis virus in cultured peripheral blood lymphocytes," Science, vol. 241, no. 4870, pp. 1213-1216, 1988.

[98] P. J. Cote and J. L. Gerin, "In vitro activation of woodchuck lymphocytes measured by radiopurine incorporation and interleukin-2 production: implications for modeling immunity and therapy in hepatitis B virus infection," Hepatology, vol. 22, no. 3, pp. 687-699, 1995.

[99] S. Menne, C. A. Roneker, M. Roggendorf, J. L. Gerin, P. J. Cote, and B. C. Tennant, "Deficiencies in the acutephase cell-mediated immune response to viral antigens are associated with development of chronic woodchuck hepatitis virus infection following neonatal inoculation," Journal of Virology, vol. 76, no. 4, pp. 1769-1780, 2002.

[100] M. R. Betts, J. M. Brenchley, D. A. Price et al., "Sensitive and viable identification of antigen-specific $\mathrm{CD}^{+} \mathrm{T}$ cells by a flow cytometric assay for degranulation," Journal of Immunological Methods, vol. 281, no. 1-2, pp. 65-78, 2003.

[101] V. Rubio, T. B. Stuge, N. Singh et al., "Ex vivo identification, isolation and analysis of tumor-cytolytic T cells," Nature Medicine, vol. 9, no. 11, pp. 1377-1382, 2003.

[102] M. Lu and M. Roggendorf, "Evaluation of new approaches to prophylactic and therapeutic vaccinations against hepatitis B viruses in the woodchuck model," Intervirology, vol. 44, no. 2-3, pp. 124-131, 2001.

[103] M. Roggendorf and M. Lu, "Therapeutic vaccination in chronic hepadnavirus infection," in New Concepts of Antiviral 
Therapy, E. Dogner and A. Holzenburg, Eds., pp. 3-20, Springer, Berlin, Germany, 2006.

[104] J. Summers, "Three recently described animal virus models for human hepatitis B virus," Hepatology, vol. 1, no. 2, pp. 179-183, 1981.

[105] T. J. Liang, "Hepatitis B: the virus and disease," Hepatology, vol. 49, no. 5, pp. S13-21, 2009.

[106] M. Flajolet, P. Tiollais, M.-A. Buendia, and G. Fourel, "Woodchuck hepatitis virus enhancer I and enhancer II are both involved in N-myc2 activation in woodchuck liver tumors," Journal of Virology, vol. 72, no. 7, pp. 6175-6180, 1998.

[107] Y. Wang, S. Menne, B. H. Baldwin, B. C. Tennant, J. L. Gerin, and P. J. Cote, "Kinetics of viremia and acute liver injury in relation to outcome of neonatal woodchuck hepatitis virus infection," Journal of Medical Virology, vol. 72, no. 3, pp. 406415, 2004.

[108] S. Hervás-Stubbs, J. J. Lasarte, P. Sarobe et al., “T-helper cell response to woodchuck hepatitis virus antigens after therapeutic vaccination of chronically-infected animals treated with lamivudine," Journal of Hepatology, vol. 35, no. 1, pp. 105-111, 2001.

[109] S. Menne, C. A. Roneker, B. E. Korba, et al., "Breaking T cell tolerance in chronic WHV infection by vaccination with WHsAg alone and in combination with the antiviral drug LFMAU," Antiviral Therapy, vol. 5, p. B58, 2000.

[110] S. Menne, C. A. Roneker, B. C. Tennant, B. E. Korba, J. L. Gerin, and P. J. Cote, "Immunogenic effects of woodchuck hepatitis virus surface antigen vaccine in combination with antiviral therapy: breaking of humoral and cellular immune tolerance in chronic woodchuck hepatitis virus infection," Intervirology, vol. 45, no. 4-6, pp. 237-250, 2002.

[111] B. E. Korba, P. J. Cote, S. Menne et al., "Clevudine therapy with vaccine inhibits progression of chronic hepatitis and delays onset of hepatocellular carcinoma in chronic woodchuck hepatitis virus infection," Antiviral Therapy, vol. 9, no. 6, pp. 937-952, 2004.

[112] M. Lu, L. F. He, Y. Xu, et al., "Evaluation of combination therapies of chronic HBV infection with lamivudine and DNAvaccines or antigen-antibody complexes in the woodchuck model," The Journal of Virology, vol. 82, pp. 2598-2603, 2008.

[113] B. E. Korba, P. Cote, W. Hornbuckle et al., "Enhanced antiviral benefit of combination therapy with lamivudine and alpha interferon against WHV replication in chronic carrier woodchucks," Antiviral Therapy, vol. 5, no. 2, pp. 95-104, 2000.

[114] J. M. Cullen, D. H. Li, C. Brown et al., "Antiviral efficacy and pharmacokinetics of oral adefovir dipivoxil in chronically woodchuck hepatitis virus-infected woodchucks," Antimicrobial Agents and Chemotherapy, vol. 45, no. 10, pp. 2740-2745, 2001.

[115] E. V. Genovesi, L. Lamb, I. Medina et al., "Efficacy of the carbocyclic 2 '-deoxyguanosine nucleoside BMS-200475 in the woodchuck model of hepatitis B virus infection," Antimicrobial Agents and Chemotherapy, vol. 42, no. 12, pp. 3209-3217, 1998.

[116] B. E. Korba, R. F. Schinazi, P. Cote, B. C. Tennant, and J. L. Gerin, "Effect of oral administration of emtricitabine on woodchuck hepatitis virus replication in chronically infected woodchucks," Antimicrobial Agents and Chemotherapy, vol. 44, no. 6, pp. 1757-1760, 2000.

[117] D. N. Standring, E. G. Bridges, L. Placidi et al., "Antiviral $\beta$-Lnucleosides specific for hepatitis B virus infection," Antiviral
Chemistry and Chemotherapy, vol. 12, no. 1, supplement, pp. 119-129, 2001.

[118] M. L. Bryant, E. G. Bridges, L. Placidi et al., "Antiviral Lnucleosides specific for hepatitis B virus infection," Antimicrobial Agents and Chemotherapy, vol. 45, no. 1, pp. 229-235, 2001.

[119] J. R. Jacob, B. E. Korba, P. J. Cote et al., "Suppression of lamivudine-resistant B-domain mutants by adefovir dipivoxil in the woodchuck hepatitis virus model," Antiviral Research, vol. 63, no. 2, pp. 115-121, 2004.

[120] S. Hervás-Stubbs, J.-J. Lasarte, P. Sarobe et al., "Therapeutic vaccination of woodchucks against chronic woodchuck hepatitis virus infection," Journal of Hepatology, vol. 27, no. 4, pp. 726-737, 1997.

[121] M. Lu, R. Klaes, S. Menne et al., "Induction of antibodies to the PreS region of surface antigens of woodchuck hepatitis virus (WHV) in chronic carrier woodchucks by immunizations with WHV surface antigens," Journal of Hepatology, vol. 39, no. 3, pp. 405-413, 2003.

[122] M.-L. Michel and D. Loirat, "DNA vaccines for prophylactic or therapeutic immunization against hepatitis B," Intervirology, vol. 44, no. 2-3, pp. 78-87, 2001.

[123] M. Lu, G. Hilken, J. Kruppenbacher et al., "Immunization of woodchucks with plasmids expressing woodchuck hepatitis virus (WHV) core antigen and surface antigen suppresses WHV infection," Journal of Virology, vol. 73, no. 1, pp. 281289, 1999.

[124] W. S. Mason, J. Cullen, G. Moraleda et al., "Lamivudine therapy of WHV-infected woodchucks," Virology, vol. 245, no. 1, pp. 18-32, 1998.

[125] X. Danthinne and M. J. Imperiale, "Production of first generation adenovirus vectors: a review," Gene Therapy, vol. 7, no. 20, pp. 1707-1714, 2000.

[126] A. R. Pinto and H. C. Ertl, "Genetically modified adenoviruses as recombinant vaccines," Current Topics in Virology, vol. 2, pp. 70-84, 2002.

[127] N. Tatsis and H. C. Ertl, "Adenoviruses as vaccine vectors," Molecular Therapy, vol. 10, no. 4, pp. 616-629, 2004.

[128] E. Paoletti, "Applications of pox virus vectors to vaccination: an update," Proceedings of the National Academy of Sciences of the United States of America, vol. 93, no. 21, pp. 11349-11353, 1996.

[129] H. L. Robinson, "New hope for an aids vaccine," Nature Reviews Immunology, vol. 2, no. 4, pp. 239-250, 2002.

[130] M. E. Perkus, A. Piccini, B. R. Lipinskas, and E. Paoletti, "Recombinant vaccinia virus: immunization against multiple pathogens," Science, vol. 229, no. 4717, pp. 981-984, 1985.

[131] M. Sällberg, J. Hughes, A. Javadian et al., "Genetic immunization of chimpanzees chronically infected with the hepatitis $B$ virus, using a recombinant retroviral vector encoding the hepatitis B virus core antigen," Human Gene Therapy, vol. 9, no. 12, pp. 1719-1729, 1998.

[132] S. Hacein-Bey-Abina, C. Von Kalle, M. Schmidt et al., "LMO2-Associated Clonal T Cell Proliferation in Two Patients after Gene Therapy for SCID-X1," Science, vol. 302, no. 5644, pp. 415-419, 2003.

[133] K. Schwarzwaelder, S. J. Howe, M. Schmidt et al., "Gammaretrovirus-mediated correction of SCID-X1 is associated with skewed vector integration site distribution in vivo," Journal of Clinical Investigation, vol. 117, no. 8, pp. 2241-2249, 2007.

[134] N. Khalighinejad, H. Hariri, O. Behnamfar, A. Yousefi, and A. Momeni, "Adenoviral gene therapy in gastric cancer: 
a review," World Journal of Gastroenterology, vol. 14, no. 2, pp. 180-184, 2008.

[135] K. F. D. Kuhlmann, D. J. Gouma, and J. G. Wesseling, "Adenoviral gene therapy for pancreatic cancer: where do we stand?” Digestive Surgery, vol. 25, no. 4, pp. 278-292, 2008.

[136] K. S. Matthews, R. D. Alvarez, and D. T. Curiel, "Advancements in adenoviral based virotherapy for ovarian cancer," Advanced Drug Delivery Reviews, vol. 61, no. 10, pp. 836-841, 2009.

[137] T. Wirth, H. Samaranayake, J. Pikkarainen, A. M. Määttä, and S. Ylä-Herttuala, "Clinical trials for glioblastoma multiforme using adenoviral vectors," Current Opinion in Molecular Therapeutics, vol. 11, no. 5, pp. 485-492, 2009.

[138] Z. Q. Xiang, Y. Yang, J. M. Wilson, and H. C. J. Ertl, “A replication-defective human adenovirus recombinant serves as a highly efficacious vaccine carrier," Virology, vol. 219, no. 1, pp. 220-227, 1996.

[139] J. W. Shiver, T.-M. Fu, L. Chen et al., "Replicationincompetent adenoviral vaccine vector elicits effective antiimmunodeficiency-virus immunity," Nature, vol. 415, no. 6869, pp. 331-335, 2002.

[140] J. C. Fitzgerald, G.-P. Gao, A. Reyes-Sandoval et al., "A simian replication-defective adenoviral recombinant vaccine to HIV-1 gag," Journal of Immunology, vol. 170, no. 3, pp. 1416-1422, 2003.

[141] A. N. Zakhartchouk, S. Viswanathan, J. B. Mahony, J. Glaudei, and L. A. Babiuk, "Severe acute respiratory syndrome coronavirus nucleocapsid protein expressed by an adenovirus vector is phosphorylated and immunogenic in mice," Journal of General Virology, vol. 86, no. 1, pp. 211-215, 2005.

[142] A. E. Morelli, A. T. Larregina, R. W. Ganster et al., "Recombinant adenovirus induces maturation of dendritic cells via an NF- $\kappa$ B-dependent pathway," Journal of Virology, vol. 74, no. 20, pp. 9617-9628, 2000.

[143] C. Pasare and R. Medzhitov, "Toll pathway-dependent blockade of $\mathrm{CD} 4^{+} \mathrm{CD} 25^{+} \mathrm{T}$ cell-mediated suppression by dendritic cells," Science, vol. 299, no. 5609, pp. 1033-1036, 2003.

[144] S. Wan, C. Xia, and L. Morel, "IL-6 produced by dendritic cells from lupus-prone mice inhibits $\mathrm{CD} 4^{+} \mathrm{CD} 25^{+} \mathrm{T}$ cell regulatory functions," Journal of Immunology, vol. 178, no. 1, pp. 271-279, 2007.

[145] S. F. Farina, G.-P. Gao, Z. Q. Xiang et al., "Replicationdefective vector based on a chimpanzee adenovirus," Journal of Virology, vol. 75, no. 23, pp. 11603-11613, 2001.

[146] J. Cohen, "Did Merck's failed HIV vaccine cause harm?" Science, vol. 318, no. 5853, pp. 1048-1049, 2007.

[147] S. P. Buchbinder, D. V. Mehrotra, A. Duerr et al., "Efficacy assessment of a cell-mediated immunity HIV-1 vaccine (the Step Study): a double-blind, randomised, placebocontrolled, test-of-concept trial," The Lancet, vol. 372, no. 9653, pp. 1881-1893, 2008.

[148] M. J. McElrath, S. C. De Rosa, Z. Moodie et al., "HIV-1 vaccine-induced immunity in the test-of-concept Step Study: a case-cohort analysis," The Lancet, vol. 372, no. 9653, pp. 1894-1905, 2008.

[149] W. Gao, P. D. Robbins, and A. Gambotto, "Human adenovirus type 35: nucleotide sequence and vector development," Gene Therapy, vol. 10, no. 23, pp. 1941-1949, 2003.

[150] D. H. Barouch, M. G. Pau, J. H. H. V. Custers et al., "Immunogenicity of recombinant adenovirus serotype 35 vaccine in the presence of pre-existing anti-Ad5 immunity," Journal of Immunology, vol. 172, no. 10, pp. 6290-6297, 2004.
[151] D. S. Bangari and S. K. Mittal, "Development of nonhuman adenoviruses as vaccine vectors," Vaccine, vol. 24 , no. 7, pp. 849-862, 2006.

[152] D. R. Casimiro, F. Wang, W. A. Schleif et al., "Attenuation of simian immunodeficiency virus SIVmac239 infection by prophylactic immunization with DNA and recombinant adenoviral vaccine vectors expressing Gag," Journal of Virology, vol. 79, no. 24, pp. 15547-15555, 2005.

[153] K.-Q. Xin, N. Jounai, K. Someya et al., "Prime-boost vaccination with plasmid DNA and a chimeric adenovirus type 5 vector with type 35 fiber induces protective immunity against HIV," Gene Therapy, vol. 12, no. 24, pp. 1769-1777, 2005.

[154] N. J. Sullivan, A. Sanchez, P. E. Rollin, Z.-Y. Yang, and G. J. Nabel, "Development of a preventive vaccine for Ebola virus infection in primates," Nature, vol. 408, no. 6812, pp. 605$609,2000$.

[155] H. Kibuuka, R. Kimutai, L. Maboko et al., "A phase 1/2 study of a multiclade HIV-1 DNA plasmid prime and recombinant adenovirus serotype 5 boost vaccine in HIV-uninfected east africans (RV 172)," Journal of Infectious Diseases, vol. 201, no. 4, pp. 600-607, 2010.

[156] S. Hermening, S. Kügler, M. Bähr, and S. Isenmann, "Increased protein expression from adenoviral shuttle plasmids and vectors by insertion of a small chimeric intron sequence," Journal of Virological Methods, vol. 122, no. 1, pp. 73-77, 2004.

[157] F. Sakurai, K. Kawabata, T. Yamaguchi, T. Hayakawa, and H. Mizuguchi, "Optimization of adenovirus serotype 35 vectors for efficient transduction in human hematopoietic progenitors: comparison of promoter activities," Gene Therapy, vol. 12, no. 19, pp. 1424-1433, 2005.

[158] H.-W. Li, Y.-X. Gao, M. K. Raizada, and C. Sumners, "Intronic enhancement of angiotensin II type 2 receptor transgene expression in vitro and in vivo," Biochemical and Biophysical Research Communications, vol. 336, no. 1, pp. 29$35,2005$.

[159] Q. Li, M. A. Kay, M. Finegold, L. D. Stratford-Perricaudet, and S. L. C. Woo, "Assessment of recombinant adenoviral vectors for hepatic gene therapy," Human Gene Therapy, vol. 4, no. 4, pp. 403-409, 1993.

[160] H. A. Jaffe, G. Danel, G. Longenecker et al., "Adenovirusmediated in vivo gene transfer and expression in normal rat liver," Nature Genetics, vol. 1, no. 5, pp. 372-378, 1992.

[161] V. Schmitz, C. Qian, J. Ruiz et al., "Gene therapy for liver diseases: recent strategies for treatment of viral hepatitis and liver malignancies," Gut, vol. 50, no. 1, pp. 130-135, 2002.

[162] A. Józkowicz and J. Dulak, "Helper-dependent adenoviral vectors in experimental gene therapy," Acta Biochimica Polonica, vol. 52, no. 3, pp. 589-599, 2005.

[163] M. Fiedler, F. Rödicker, V. Salucci et al., "Helper-dependent adenoviral vector-mediated delivery of woodchuck-specific genes for alpha interferon (IFN- $\alpha$ ) and IFN- $\gamma$ : IFN- $\alpha$ but not IFN- $\gamma$ reduces woodchuck hepatitis virus replication in chronic infection in vivo," Journal of Virology, vol. 78, no. 18, pp. 10111-10121, 2004.

[164] A. C. Jacquard, M. Nassal, C. Pichoud et al., "Effect of a combination of clevudine and emtricitabine with adenovirusmediated delivery of gamma interferon in the woodchuck model of hepatitis B virus infection," Antimicrobial Agents and Chemotherapy, vol. 48, no. 7, pp. 2683-2692, 2004.

[165] Y. Zhu, J. M. Cullen, C. E. Aldrich et al., "Adenovirus-based gene therapy during clevudine treatment of woodchucks 
chronically infected with woodchuck hepatitis virus," Virology, vol. 327, no. 1, pp. 26-40, 2004.

[166] J. Crettaz, I. Otano, L. Ochoa et al., "Treatment of chronic viral hepatitis in woodchucks by prolonged intrahepatic expression of interleukin-12," Journal of Virology, vol. 83, no. 6, pp. 2663-2674, 2009.

[167] R. Bilbao, R. Gérolami, M.-P. Bralet et al., "Transduction efficacy, antitumoral effect, and toxicity of adenovirusmediated herpes simplex virus thymidine kinase/ganciclovir therapy of hepatocellular carcinoma: the woodchuck animal model," Cancer Gene Therapy, vol. 7, no. 5, pp. 657-662, 2000.

[168] B. M. Pützer, T. Stiewe, F. Rödicker et al., "Large nontransplanted hepatocellular carcinoma in woodchucks: treatment with adenovirus-mediated delivery of interleukin 12/B7.1 genes," Journal of the National Cancer Institute, vol. 93, no. 6, pp. 472-479, 2001.

[169] V. Salucci, M. Lu, L. Aurisicchio, N. La Monica, M. Roggendorf, and F. Palombo, "Expression of a new woodchuck IFN- $\alpha$ gene by a helper-dependent adenoviral vector in woodchuck hepatitis virus-infected primary hepatocytes," Journal of Interferon and Cytokine Research, vol. 22, no. 10, pp. 1027-1034, 2002.

[170] T. Zhou, J.-T. Guo, F. A. Nunes et al., "Combination therapy with lamivudine and adenovirus causes transient suppression of chronic woodchuck hepatitis virus infections," Journal of Virology, vol. 74, no. 24, pp. 11754-11763, 2000.

[171] M. Lu, B. Lohrengel, G. Hilken, T. Kemper, and M. Roggendorf, "Woodchuck gamma interferon upregulates major histocompatibility complex class I transcription but is unable to deplete woodchuck hepatitis virus replication intermediates and RNAs in persistently infected woodchuck primary hepatocytes," Journal of Virology, vol. 76, no. 1, pp. 58-67, 2002.

[172] J.-T. Guo, H. Zhou, C. Liu et al., "Apoptosis and regeneration of hepatocytes during recovery from transient hepadnavirus infections," Journal of Virology, vol. 74, no. 3, pp. 1495-1505, 2000.

[173] T. I. Michalak, P. D. Hodgson, and N. D. Churchill, "Posttranscriptional inhibition of class I major histocompatibility I complex presentation on hepatocytes and lymphoid cells in chronic woodchuck hepatitis virus infection," Journal of Virology, vol. 74, no. 10, pp. 4483-4494, 2000.

[174] G. Trinchieri, "Interleukin-12 and the regulation of innate resistance and adaptive immunity," Nature Reviews Immunology, vol. 3, no. 2, pp. 133-146, 2003.

[175] E. Vattemi and P. P. Claudio, "Adenoviral gene therapy in head and neck cancer," Drug News and Perspectives, vol. 19, no. 6, pp. 329-337, 2006.

[176] K. S. Matthews, R. D. Alvarez, and D. T. Curiel, "Advancements in adenoviral based virotherapy for ovarian cancer," Advanced Drug Delivery Reviews, vol. 61, no. 10, pp. 836-841, 2009.

[177] K. F. D. Kuhlmann, D. J. Gouma, and J. G. Wesseling, "Adenoviral gene therapy for pancreatic cancer: where do we stand?" Digestive Surgery, vol. 25, no. 4, pp. 278-292, 2008.

[178] N. Khalighinejad, H. Hariri, O. Behnamfar, A. Yousefi, and A. Momeni, "Adenoviral gene therapy in gastric cancer: a review," World Journal of Gastroenterology, vol. 14, no. 2, pp. 180-184, 2008.

[179] C. L. Addison, J. L. Bramson, M. M. Hitt, W. J. Muller, J. Gauldie, and F. L. Graham, "Intratumoral coinjection of adenoviral vectors expressing IL-2 and IL-12 results in enhanced frequency of regression of injected and untreated distal tumors," Gene Therapy, vol. 5, no. 10, pp. 1400-1409, 1998.

[180] J. L. Bramson, M. Hitt, C. L. Addison, W. J. Muller, J. Gauldie, and F. L. Graham, "Direct intratumoral injection of an adenovirus expressing interleukin-12 induces regression and long-lasting immunity that is associated with highly localized expression of interleukin-12," Human Gene Therapy, vol. 7, no. 16, pp. 1995-2002, 1996.

[181] B. M. Pützer, M. Hitt, W. J. Muller, P. Emtage, J. Gauldie, and F. L. Graham, "Interleukin 12 and B7-1 costimulatory molecule expressed by an adenovirus vector act synergistically to facilitate tumor regression," Proceedings of the National Academy of Sciences of the United States of America, vol. 94, no. 20, pp. 10889-10894, 1997.

[182] M. Malvicini, M. Rizzo, L. Alaniz et al., "A novel synergistic combination of cyclophosphamide and gene transfer of interleukin-12 eradicates colorectal carcinoma in mice," Clinical Cancer Research, vol. 15, no. 23, pp. 7256-7265, 2009.

[183] S. Bortolanza, M. Bunuales, I. Otano et al., "Treatment of pancreatic cancer with an oncolytic adenovirus expressing interleukin-12 in Syrian hamsters," Molecular Therapy, vol. 17, no. 4, pp. 614-622, 2009.

[184] M. Drozdzik, C. Qian, X. Xie et al., "Combined gene therapy with suicide gene and interleukin-12 is more efficient than therapy with one gene alone in a murine model of hepatocellular carcinoma," Journal of Hepatology, vol. 32, no. 2, pp. 279-286, 2000.

[185] M. M. B. Rodríguez, S.-M. Ryu, C. Qian et al., "Immunotherapy of murine hepatocellular carcinoma by $\alpha$-fetoprotein DNA vaccination combined with adenovirus-mediated chemokine and cytokine expression," Human Gene Therapy, vol. 19, no. 7, pp. 753-759, 2008.

[186] B. Gückel, G. C. Meyer, W. Rudy et al., "Interleukin-12 requires initial CD80-mediated T-cell activation to support immune responses toward human breast and ovarian carcinoma," Cancer Gene Therapy, vol. 6, no. 3, pp. 228-237, 1999.

[187] M. Kuiper, R. Sanches, Y.-J. Bignon, and F. Farzaneh, "B7.1 and Cytokines: synergy in cancer gene therapy," Advances in Experimental Medicine and Biology, vol. 465, pp. 381-390, 2000.

[188] J. Wu, Z. Meng, M. Jiang et al., "Hepatitis B virus suppresses toll-like receptor-mediated innate immune responses in murine parenchymal and nonparenchymal liver cells," Hepatology, vol. 49, no. 4, pp. 1132-1140, 2009.

[189] K. Visvanathan, N. A. Skinner, A. J. V. Thompson et al., "Regulation of Toll-like receptor-2 expression in chronic hepatitis B by the precore protein," Hepatology, vol. 45, no. 1, pp. 102-110, 2007.

[190] Z. Chen, Y. Cheng, Y. Xu et al., "Expression profiles and function of Toll-like receptors 2 and 4 in peripheral blood mononuclear cells of chronic hepatitis B patients," Clinical Immunology, vol. 128, no. 3, pp. 400-408, 2008. 


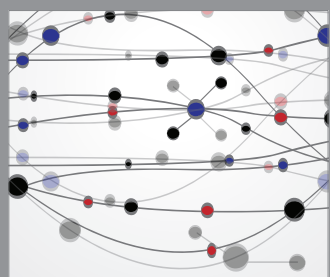

The Scientific World Journal
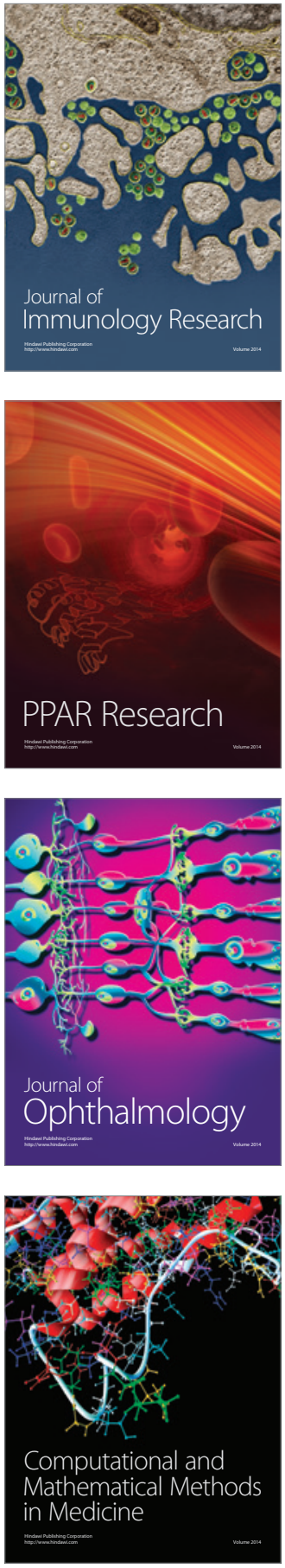

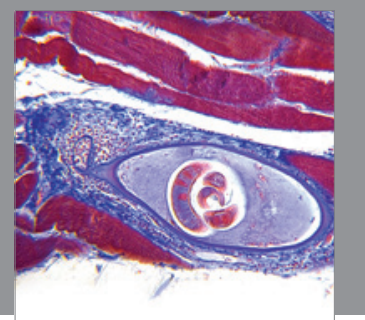

Gastroenterology

Research and Practice
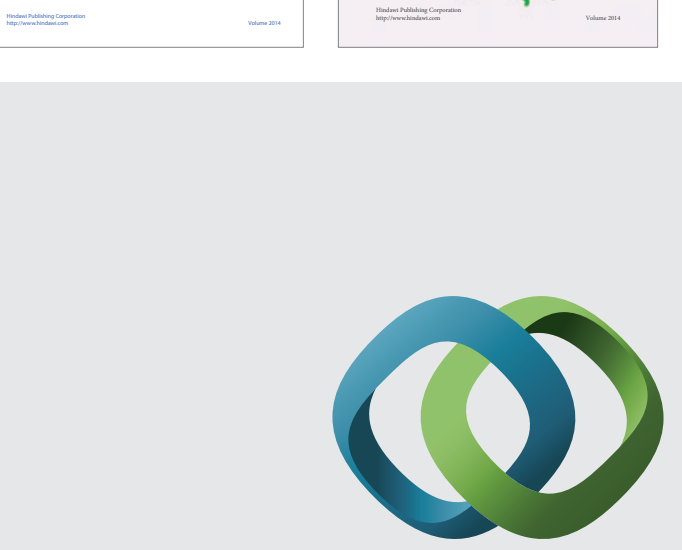

\section{Hindawi}

Submit your manuscripts at

http://www.hindawi.com
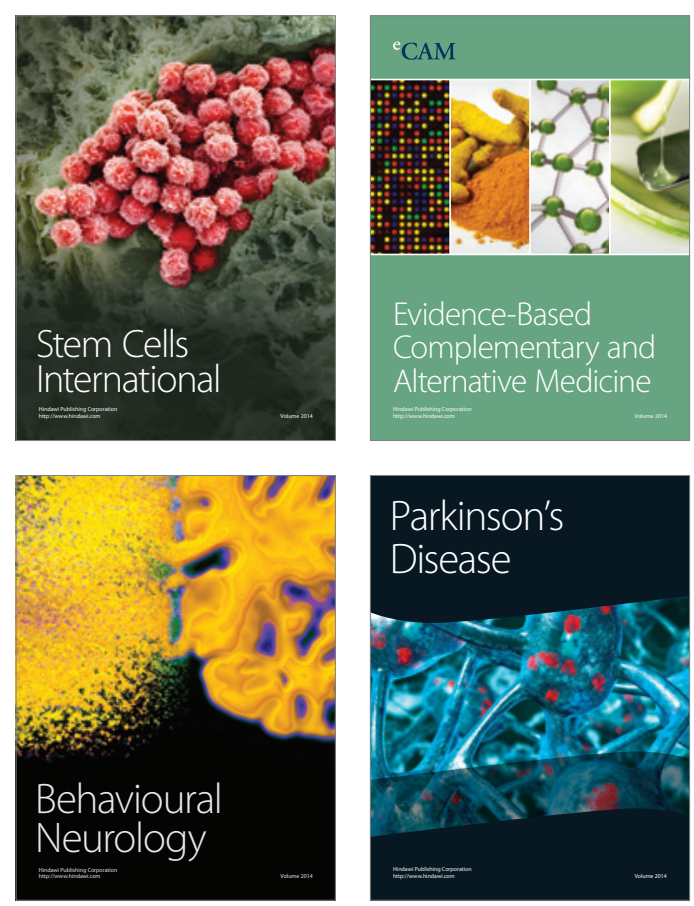

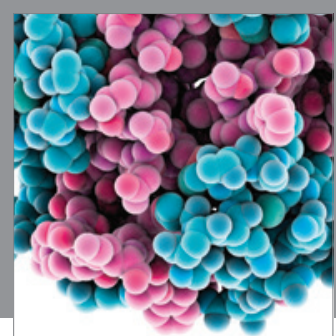

Journal of
Diabetes Research

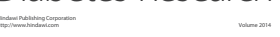

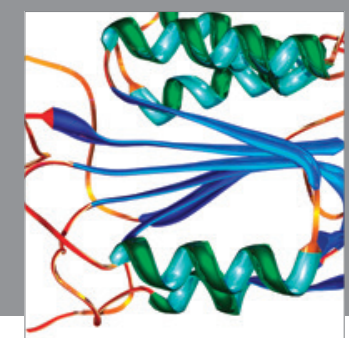

Disease Markers
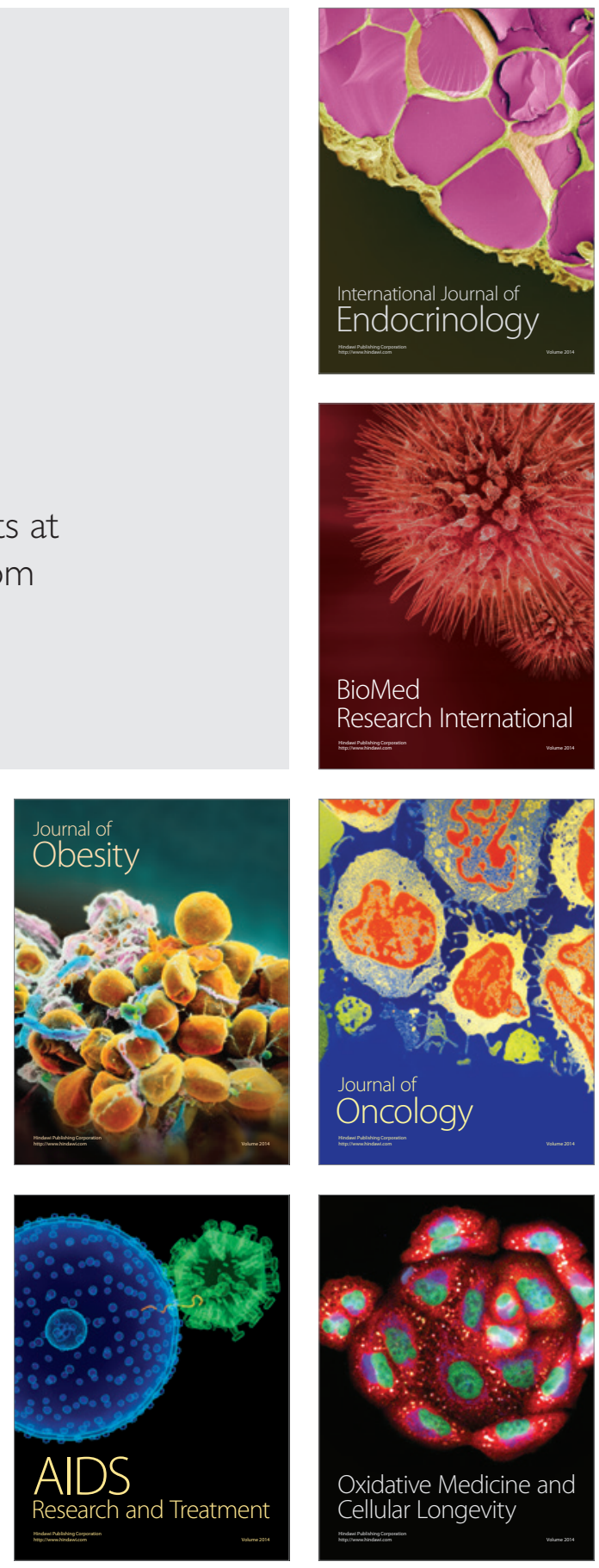